\title{
Coupled Fe and S isotope variations in pyrite nodules from Archean shale
}

\author{
Johanna Marin-Carbonne ${ }^{\mathrm{a}, \mathrm{b}, *}$, Claire Rollion-Bard ${ }^{\mathrm{c}}$, Andrey Bekker ${ }^{\mathrm{d}}$, Olivier Rouxel ${ }^{\mathrm{e}}$, Andrea Agangi $\mathrm{f}^{\mathrm{f}}$, \\ Barbara Cavalazzif $^{\mathrm{f} g}$, Cora C. Wohlgemuth-Ueberwasser ${ }^{\mathrm{f},}$, Axel Hofmann ${ }^{f}$ and Kevin D. McKeegan ${ }^{\mathrm{a}}$
}

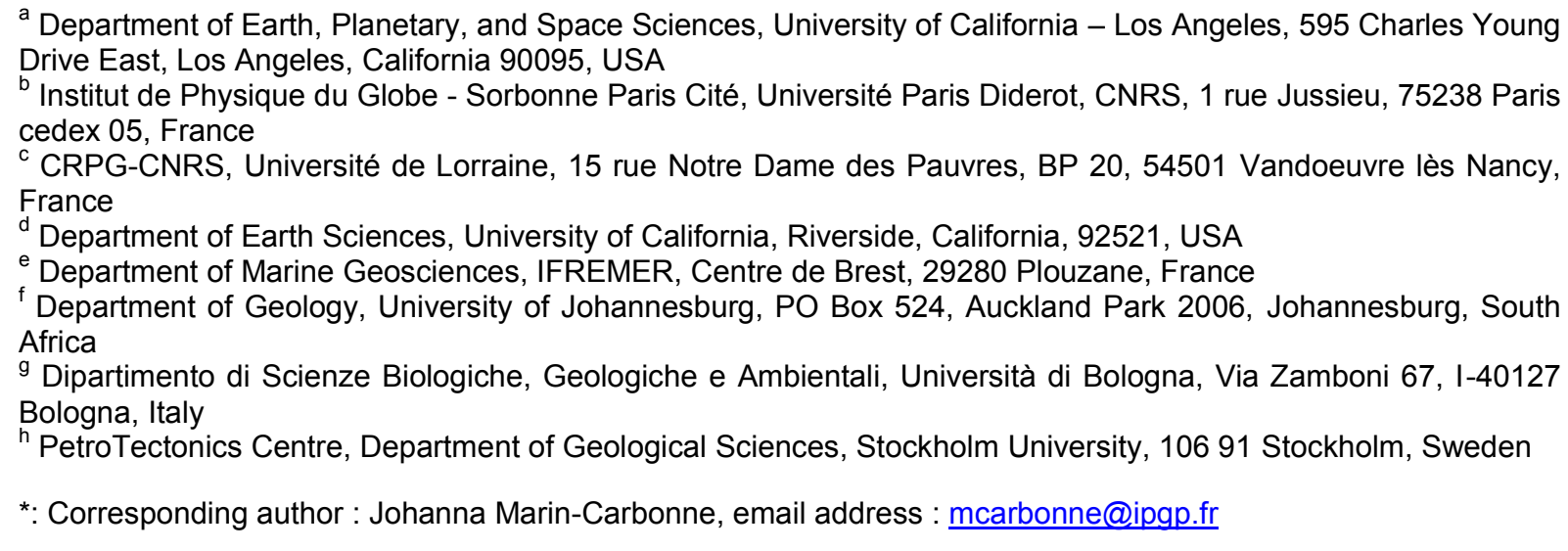

\section{Abstract:}

Iron and sulfur isotope compositions recorded in ancient rocks and minerals such as pyrite $\left(\mathrm{FeS}_{2}\right)$ have been widely used as a proxy for early microbial metabolisms and redox evolution of the oceans. However, most previous studies focused on only one of these isotopic systems. Herein, we illustrate the importance of in-situ and coupled study of Fe and S isotopes on two pyrite nodules in a c. $2.7 \mathrm{Ga}$ shale from the Bubi Greenstone Belt (Zimbabwe). Fe and $\mathrm{S}$ isotope compositions were measured both by bulk-sample mass spectrometry techniques and by ion microprobe in-situ methods (Secondary lon Mass Spectrometry, SIMS). Spatially-resolved analysis across the nodules shows a large range of variations at micrometer-scale for both $\mathrm{Fe}$ and $\mathrm{S}$ isotope compositions, with $\delta^{56} \mathrm{Fe} \delta 56 \mathrm{Fe}$ and $\delta^{34} \mathrm{~S} \delta 34 \mathrm{~S}$ values from -2.1 to $+0.7 \%+0.7 \%$ and from -0.5 to $+8.2 \%$ o $+8.2 \%$, respectively, and $\Delta^{33} \mathrm{~S} \triangle 33 \mathrm{~S}$ values from -1.6 to $+2.9 \%+2.9 \%$. The $\mathrm{Fe}$ and $\mathrm{S}$ isotope variations in these nodules cannot be explained by tandem operation of Dissimilatory Iron Reduction (DIR) and Bacterial Sulfate Reduction (BSR) as was previously proposed, but rather they reflect the contributions of different Fe and $\mathrm{S}$ sources during a complex diagenetic history. Pyrite formed from two different mineral precursors: (1) mackinawite precipitated in the water column, and (2) greigite formed in the sediment during early diagenesis. The in-situ analytical approach reveals a complex history of the pyrite nodule growth and allows us to better constrain environmental conditions during the Archean

\section{Highlights}

In-situ and bulk Fe and S isotopes analyses of Archean pyrite nodules. Nodules formed from 2 different precursors during complex diagenetic history. Presence of two distincts seawater $S$ pools, derived from the atmosphere.

Keywords: pyrite nodules ; Fe and S isotopes ; Archean ; SIMS

\section{Introduction}

Variations in Fe and $\mathrm{S}$ isotope composition of sedimentary pyrites have placed important constraints on the chemistry and redox evolution of the Earth's ocean and atmosphere over 
geological time (e.g. Bekker et al., 2004; Farquhar et al., 2000; Johnson et al., 2008; Rouxel et al., 2003; Rouxel et al., 2005; Strauss, 2003). These variations record isotope fractionations during redox reactions, which in some cases might have been biologically mediated (Archer and Vance, 2006; Beard et al., 1999; Johnson et al., 2008). Sulfur isotopes have been used to document ancient microbial metabolisms, because the fractionations produced by living organisms can be large and reflect specific metabolic activity (e.g. Johnston, 2011). Indeed, in the process called Bacterial Sulfate Reduction (BSR), dissolved sulfate is used by eukaryotes, bacteria, and certain groups of Archea as an electron acceptor during organic $\mathrm{C}$ remineralization or $\mathrm{H}_{2}$ oxidation. In other redox reactions, hydrogen sulfide can act as an electron donor associated with $\mathrm{O}_{2}, \mathrm{NO}_{3}$ or $\mathrm{CO}_{2}$ reduction (Canfield, 2001). BSR preferentially metabolizes ${ }^{32} \mathrm{~S}$ relative to ${ }^{34} \mathrm{~S}$, thereby producing fractionation of the $\mathrm{S}$ isotopes up to $70 \%$ (Canfield, 2001; Sim et al., 2011).

The discovery of mass-independent fractionation (MIF) of $\mathrm{S}$ isotopes in Archean sedimentary sulfides and sulfates (Farquhar et al., 2000) has deeply modified our understanding of the Precambrian sulfur cycle. The prevailing hypothesis to explain S-MIF is based on experimental studies and atmospheric models that invoke photochemical reactions, and suggest an absence of atmospheric oxygen before $2.4 \mathrm{Ga}$ (Farquhar et al., 2000; Ono et al., 2003b; Pavlov and Kasting, 2002). Farquhar et al. (2001) suggested that Archean S-MIF was created via photolysis of $\mathrm{SO}_{2}$ and/or $\mathrm{SO}$ by short ultraviolet radiation $(<220 \mathrm{~nm})$ that penetrated deeply into the Archean atmosphere due to the lack of $\mathrm{O}_{2} \cdot \mathrm{SO}_{2}$ photodissociation in an oxygen-free atmosphere produces water-soluble $\mathrm{SO}_{4}{ }^{2-}$ with negative $\Delta^{33} \mathrm{~S}$ values and elemental sulfur aerosols, mostly $\mathrm{S}_{8}$, with positive $\Delta^{33} \mathrm{~S}$ values (Farquhar et al., 2000). Although alternative views are still debated (see for alternative view Oduro et al., 2011; e.g., Ohmoto et al., 2006), $\mathrm{O}_{2}$ level 
below $10^{-5}$ Present Atmospheric Level (PAL) is considered critical for the production of massindependent fractionation in $\mathrm{S}$ isotopes and its preservation in the sedimentary rock record (Thiemens, 2001). Based on photochemical experiments, it was proposed that Archean seawater sulfate had negative $\Delta^{33} \mathrm{~S}$ values (Farquhar et al., 2000; Ono et al., 2009; Ono et al., 2003b), whereas Archean disseminated pyrites have mostly positive $\Delta^{33} \mathrm{~S}$ values (Farquhar and Wing, 2003). This is consistent with $\mathrm{S}$ isotope composition of hydrothermal barite and sulphide in base-metal barren, distal exhalite deposits (e.g., Farquhar and Wing, 2003), which derived their S from seawater sulfate in distal, hydrothermally-influenced low-energy environments.

The Fe isotope composition of sedimentary pyrite is highly sensitive to the size of dissolved $\mathrm{Fe}(\mathrm{II})$ and $\mathrm{S}$ reservoirs and hence can place important constrains on the redox state and chemistry of Precambrian oceans (Guilbaud et al., 2011; Rouxel et al., 2005). Iron isotopes fractionate through both redox and non-redox reactions (e.g Johnson and Beard, 2005). Hence interpretation of iron isotope record of Fe-bearing marine deposits requires an understanding of Fe sources and formation mechanisms of iron-bearing minerals, including oxides, sulphides, carbonates, and silicates, in marine sediments. Each of these minerals can have various origins, such as detrital, biochemical and hydrothermal, and thus can record different $\mathrm{Fe}$ isotope fractionations (Heimann et al., 2010; Johnson et al., 2008; Planavsky et al., 2009; Rouxel et al., 2005).

By coupling the $\mathrm{S}$ and $\mathrm{Fe}$ isotope systems, it is possible to gain additional insights into the processes resulting in the formation of pyrite (Archer and Vance, 2006; Fabre et al., 2011; Hofmann et al., 2009; Rouxel et al., 2008). For example, it has been proposed that coupled Fe and $\mathrm{S}$ isotope data can be used as a proxy for microbial Fe(III) and sulfate reduction, especially for Archean sediments (Archer and Vance, 2006). Studies of Archean rocks frequently use a 
bulk rock approach, although a growing number of studies focuses on individual crystals or crystal aggregates. A recent SIMS study of S isotopes of various Archean pyrites has shown large intra-grain variability in $\delta^{34} \mathrm{~S}$ values (Kamber and Whitehouse, 2007). Similarly, SIMS Fe isotope studies have also shown large ranges of $\delta^{56} \mathrm{Fe}$ values, from $+0.9 \%$ to $+5.2 \%$ in a single magnetite grain (Marin-Carbonne et al., 2011) and from $-4.2 \%$ to $+2.9 \%$ in pyrites from the 2.72 Ga Tumbiana Formation (Yoshiya et al., 2012). Such variations have been interpreted as indicating multi-stage mineral formation and/or mineral alteration processes, and highlight the importance of spatially resolved analyses to better constrain processes in the water column, and during diagenesis and, possibly, metamorphism. Pyrite nodules in Archean shales have been extensively investigated in the context of the diagenetic history of ancient sedimentary rocks and have been used as a proxy for paleoenvironmental conditions on the early Earth (Bekker et al., 2004; Kakegawa et al., 1998; Ono et al., 2009; Ono et al., 2003b; Rouxel et al., 2005). Whether there exists any isotopic variability in Fe within individual pyrite nodules is not known.

Herein, we present bulk measurements along with in-situ isotopic (Fe and S) and trace element analyses of pyrite nodules hosted in carbonaceous shale from the Late Archean (2.832.70 Ga) Bubi greenstone Belt, Zimbabwe. We use these data to constrain the origin and growth history of these pyrite nodules and to explore the possibility of a microbially-induced fractionation.

\section{Samples and Methods}

\subsection{Samples}

We investigated pyrite nodules present in Late Archean carbonaceous shales from core 690B92-02 (see supplementary material S1) drilled along the eastern margin of the Bubi 
Greenstone Belt (Zimbabwe) north of the Damba nickel prospect (Hofmann et al., 2013; Prendergast, 2003). The drill core intersects basalt and underlying carbonaceous shale (see supplementary material S2 for the detailed stratigraphic log), which are considered correlative with the 2.7 Ga Reliance Formation and the 2.83 to 2.70 Ga Manjeri Formation of the Belingwe Greenstone Belt in Zimbabwe (Hofmann and Kusky, 2004; Prendergast, 2003; Stone et al., 1994). The metamorphic grade is not well-established, but rocks in the Bubi Greenstone Belt have been subjected to lower greenschist grade metamorphism at most (Dziggel et al., 1998; Saggerson and Turner, 1976).

Pyrite occurs as nodules (up to $1 \mathrm{~cm}$ in diameter), discontinuous laminae (up to $0.5 \mathrm{~cm}$ thick), rare veinlets and disseminated grains $(<20 \mu \mathrm{m}$ in size) in the shale (Fig. 1). Pyrite formed before burial compaction at the stage of early diagenesis as indicated by ellipsoidal shape of nodules with the long axis parallel to bedding, laminations in shale that bend around the nodules and rare ptygmatically folded veinlets perpendicular to bedding. Nodules and laminae consist of either massive pyrite, a fine intergrowth of pyrite with the host matrix, or concentrations of fine pyrite crystals in the host material. The margin of nodules and laminae frequently consist of relatively coarse pyrite crystals suggestive of recrystallization. Pyrite represents the only observed Fe-sulfide mineral phase, with the exception of minor chalcopyrite crystals in the more coarsely-crystalline domains. Nodules frequently contain marginal pressure shadows elongated parallel to bedding that consists of quartz, phyllosilicates, and rare coarselycrystalline pyrite. A foliation is present in the shale and oriented at an oblique angle to bedding. A summary of pyrite textures is shown in Fig. 1.

Our study focuses on a single sample of shale (at depth of $144.5 \mathrm{~m}$ in drill core) containing several circular to slightly ellipsoidal pyrite nodules (Fig. 2). X-ray diffraction 
analysis (X-PertPro, University of Johannesburg) indicates that the shale mainly consists of quartz, illite, Fe-chlorite, and minor calcite mineral phases. The shale is relatively rich in organic carbon with $\mathrm{C}_{\text {org }}$ content ranging from 6.4 to 9.3 wt. \% (Eltra Elemental Analyzer, University of Manitoba).

\subsection{Methods}

A slab of shale containing two, immediately adjacent pyrite nodules (called nodule 1 and 2 in Fig. 2) was embedded in epoxy, polished with 1- $\mu$ m size diamond paste and Au-coated for in-situ isotopic measurements (see supplementary material S3).

\subsubsection{Bulk sample Fe and S isotope analyses}

In the following sections, iron and sulfur isotopes are expressed in delta notation $\left(\delta^{56} \mathrm{Fe}\right.$, $\delta^{33} \mathrm{~S}$, and $\delta^{34} \mathrm{~S}$ ) relative to the international standards IRMM 14 (for Fe) and V-CDT (for S) based on the following equation:

$$
\delta^{2} \mathrm{~A}=\left[\left({ }^{2} \mathrm{~A} /{ }^{1} \mathrm{~A}_{\text {sample }}\right) /\left({ }^{2} \mathrm{~A} /{ }^{1} \mathrm{~A}_{\text {standard }}\right)-1\right] \times 1000
$$

where A is Fe or S, 1 and 2 represent the heavy and light isotopes, respectively (54 and 56 for Fe and 34 or 33 and 32 for S). Mass-independent fractionation has been calculated as the deviation from the Terrestrial Fractionation Line (TFL), using the mass-discrimination law (Farquhar et al., 2000) :

$\Delta^{33} S=\left(\ln \left(\frac{\delta^{33} S}{1000}+1\right)-0.515 \times \ln \left(\frac{\delta^{34} S}{1000}\right)+1\right)$, where the factor 0.515 defines the slope of the TFL.

Pyrite nodules from the same sample of shale used for in-situ work were drilled, crushed and millimetric-sized pyrite particles were hand-picked. Sulfur isotope ratios of pyrite particles were determined at the Geophysical Laboratory using techniques described by Hu et al. (2003). Pyrite particles (0.5 to $1 \mathrm{mg}$ ) from nodules were reacted with fluorine under a $25 \mathrm{~W} \mathrm{CO}_{2}$ 
infrared laser at 25-30 Torr in a vacuum chamber to produce $\mathrm{SF}_{6}$, which was then purified by dual gas chromatography. Multiple sulfur isotope ratios were measured with a Thermo Scientific MAT 253 mass spectrometer in dual inlet mode (Hofmann et al., 2009; Ono et al., 2009). The precision for $\delta^{34} \mathrm{~S}, \delta^{33} \mathrm{~S}$, and $\Delta^{33} \mathrm{~S}$ values was determined by the multiple analyses of CDT material and internal reference materials (Maine and Alpha Aesar pyrite) and is better than 0.34 $\%$ o, $0.19 \%$, and $0.03 \%$, respectively $(2 \sigma)$.

Fe isotope compositions were measured following the procedure described in Rouxel et al. (2005). Hand-picked particles from pyrite nodules were dissolved in concentrated $\mathrm{HNO}_{3}-\mathrm{HCl}$ acid mixture and $\mathrm{Fe}$ was purified on Bio-Rad AG1X8 anion resin. Fe isotope ratios were determined with a Thermo Scientific Neptune multicollector inductively-coupled plasma massspectrometer operated at IFREMER, Pole Spectrometry Ocean, Brest in France. Long-term reproducibility of $\delta^{56} \mathrm{Fe}$ measurements was determined on duplicate analysis of reference material and is about $0.08 \% o(2 \sigma)$.

\subsubsection{SIMS analyses}

Iron isotope compositions were measured in-situ with a Cameca ims 1270 ion microprobe at both CRPG (Nancy, France) and UCLA (Los Angeles, USA) following the procedure described in detail in Marin-Carbonne et al. (2011). Briefly, a ${ }^{16} \mathrm{O}^{-}$primary beam of about $10 \mathrm{nA}$ intensity was focused to a spot of about $15 \mu \mathrm{m}$. The mass resolution was set $\sim 7,000$ and ${ }^{54} \mathrm{Fe}^{+}$and ${ }^{56} \mathrm{Fe}^{+}$were measured in multicollection mode with two off-axis Faraday cups. The gains of these Faraday cups were determined at the beginning of the analytical session and drift was monitored by frequent analyses of standards interspersed among analyses of the unknowns. The background of each detector was measured during the pre-sputtering for 1 min, i.e. at the 
beginning of each analysis. Ion currents converted to count rates were typically $\sim 2.10^{8}$ counts per second (cps) for ${ }^{56} \mathrm{Fe}$. An analysis consisted of 30 cycles with 5 sec acquisition time. Chromium was monitored on the masses 52 and 53 by using electron multipliers, but chromium levels were negligible in all samples. The internal precision for $\delta^{56} \mathrm{Fe}$ values was typically better than $0.1 \% o(2 \sigma)$, and the external reproducibility based on multiple measurements of our pyrite reference material (Balmat with $\delta^{56} \mathrm{Fe}=-0.399 \%$; Whitehouse and Fedo, 2007) was better than $0.2 \% \circ(2 \sigma)$

Sulfur isotope compositions were measured on the Cameca ims 1280 HR2 (CRPG, Nancy, France) by simultaneous measurements of ${ }^{32} \mathrm{~S}^{-},{ }^{33} \mathrm{~S}^{-}$, and ${ }^{34} \mathrm{~S}^{-}$in multicollection mode with three off-axis Faraday cups. The relative gains of the Faraday cups were intercalibrated at the beginning of each analytical session. The analytical method is described in detail in Thomassot et al. (2009) and Philippot et al. (2012) and is only summarized here. A Cs ${ }^{+}$primary beam of $5 \mathrm{nA}$ intensity was focused to a spot of about $15-20 \mu \mathrm{m}$. Typical ${ }^{32} \mathrm{~S}^{-}$intensity was between 6 and $10.10^{8}$ counts per second (cps) depending on the sulfide mineral analysed. Several pyrite standards (Maine, Philippot et al., 2012 and Balmat pyrite, courtesy of M. Whitehouse) were used to determine (i) the instrumental mass fractionation, and (ii) the reference mass discrimination line, from which $\Delta^{33} \mathrm{~S}$ values were calculated. A typical analysis consists of 2 minutes of presputtering followed by data acquisition in 30 cycles of $3 \mathrm{sec}$ each. The background of the detectors was measured during the presputtering and was then corrected for each analysis. The internal precision achieved under these conditions was better than $0.05 \%$ o

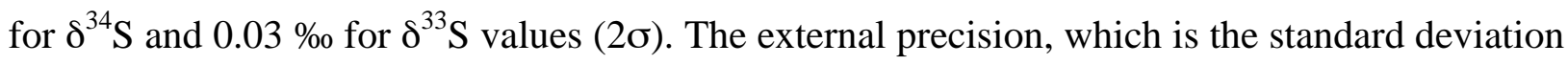
calculated from repeated measurements on various reference materials, was $0.40 \%$ ( $2 \sigma)$ for $\delta^{34} \mathrm{~S}$ and $0.06 \%$ (2б) for $\Delta^{33} \mathrm{~S}$ values. 


\section{Results}

$\mathrm{Fe}$ and $\mathrm{S}$ isotope compositions and EPMA trace element concentrations have been obtained across each nodule (see supplementary material S3 and S4), while LA-ICP-MS trace element concentration profiles were performed only for nodule 2 (see supplementary material S4).

\section{1. $\delta^{56} \mathrm{Fe}$ variations}

The two nodules show similar variations in Fe isotope composition (Fig. 3a, b). The variations are large for both nodules from -2.11 to $+0.45 \%$ for nodule 1 and from -1.58 to $+0.75 \%$ for nodule 2 , corresponding to about $2 / 3$ of the total $\delta^{56} \mathrm{Fe}$ range measured so far in bulk terrestrial rocks (Dauphas and Rouxel, 2006; Johnson et al., 2008). The total range for $\delta^{56} \mathrm{Fe}$ values from the edge to the centre is $\sim 2.5 \%$ in nodule 1 (Fig. 3a) and $\sim 2.3 \%$ in nodule 2 (Fig. 3b). The variations from the margin to the centre are consistent for both nodules. Both nodules have similar $\delta^{56} \mathrm{Fe}$ values for the rims with a mean value of $-0.4 \pm 0.4 \%$ for nodule 1 and $-0.2 \pm 0.4 \%$ for nodule 2 . The centre of the nodules is ${ }^{56} \mathrm{Fe}$-depleted with respect to the margins with a mean $\delta^{56} \mathrm{Fe}$ value of $-1.7 \pm 0.3 \%$ for nodule 1 and $-1.1 \pm 0.5 \%$ or nodule 2 . The mean $\delta^{56} \mathrm{Fe}$ values of the nodules calculated with SIMS data are $-1.1 \pm 0.7 \%$ for nodule 1 and $-0.5 \pm 0.8 \%$ for nodule 2 and are consistent with the bulk pyrite nodule value of $-1.46 \pm 0.1$ $\%$ measured on pyrite nodule fragments from the same hand-specimen.

\section{$3.2 \delta^{34} S$ variations}


The $\delta^{34} \mathrm{~S}$ values are highly variable across the nodules, without any systematic trend for nodule 1 (Fig. 3c). The centre of nodule 2 , having $\delta^{34} \mathrm{~S}$ values close to $+1 \%$, is more depleted in

${ }^{34} \mathrm{~S}$ than the rim with $\delta^{34} \mathrm{~S}$ values as high as $+8 \%$ (Fig. $3 \mathrm{~d}$ ), although there is considerable scatter in the $\delta^{34} \mathrm{~S}$ values of the rim. The total range of $\delta^{34} \mathrm{~S}$ values is $5.4 \%$ for nodule 1 and 7.8 $\%$ for nodule 2, with the mean values calculated with SIMS data of $+2.9 \pm 1.3 \%$ for nodule 1 and $+2.2 \pm 2.6 \%$ for nodule 2 . These mean values are consistent with the bulk pyrite nodule value of $+3.18 \pm 0.34 \%$, measured on pyrite nodule fragments from the same depth.

\section{$33 \Delta^{33} S$ variations}

Mass-independently fractionated sulfur (S-MIF) is present in both nodules, with $\Delta^{33} \mathrm{~S}$ values ranging between -1.5 and $+2.9 \%$ for nodule 1 and between $-1.6 \%$ and $+1.9 \%$ for nodule 2 (Fig. 3e, f). Nodule rims display mostly positive $\Delta^{33} \mathrm{~S}$ values, while their centres show predominantly negative $\Delta^{33} \mathrm{~S}$ values. The centre has a mean value of $-0.7 \pm 0.5 \%$ for nodule 1 (Fig. 3e) and $-0.7 \pm 0.6 \%$ for nodule 2 (Fig. 3f). The mean $\Delta^{33} \mathrm{~S}$ values are $-0.04 \pm 1.40 \%$ (nodule 1) and $-0.24 \pm 1.10 \%$ (nodule 2 ), which are comparable to the bulk pyrite nodule value of $0.31 \pm 0.03 \%$, considering the high variability of $\Delta^{33} \mathrm{~S}$ values at a micrometer scale measured by SIMS. The negative $\Delta^{33} \mathrm{~S}$ values of pyrite nodule cores are in the range of values measured for Archean hydrothermal barites and sulfides (Bao et al., 2007; Farquhar et al., 2000; Philippot et al., 2012; Shen et al., 2009; Ueno et al., 2008). The outer rims have positive $\Delta^{33} \mathrm{~S}$ values up to $+2.47 \%$, with a mean value of $+0.64 \pm 1.30 \%$ o for nodule 1 and $+0.6 \pm 1.30 \%$ for nodule 2 , in the range of values for disseminated pyrite in sedimentary rocks of this age (Farquhar et al., 2000; Ono et al., 2009). 


\section{Discussion}

\subsection{Nodule composed of two chemically and isotopically distinct parts: a core and a rim}

Each nodule is characterized by a core $(\sim 3000 \mu \mathrm{m}$ in width) and a more coarselycrystalline rim (Fig. 1). Both nodules broadly display similar Fe and $\mathrm{S}$ isotope trends from the core to the margin, thus potentially preserving information regarding similar processes and diagenetic histories. The rim and the core have different trace element concentrations and, more importantly, different isotopic compositions (Figs 2 and 3). The core is characterized by predominantly negative $\Delta^{33} \mathrm{~S}$ values, positive $\delta^{34} \mathrm{~S}$ values, and negative $\delta^{56} \mathrm{Fe}$ values. The rims have predominantly positive $\Delta^{33} \mathrm{~S}$ values, close to zero $\delta^{56} \mathrm{Fe}$ values and high $\mathrm{Co}$ and low $\mathrm{Ni}$ contents. The cores of both nodules show a positive correlation between $\delta^{34} S$ and $\Delta^{33} S$ values (Fig. 4), and an antithetic trend between $\delta^{56} \mathrm{Fe}$ and $\Delta^{33} \mathrm{~S}$ values (Fig. 5).

The nodules have a bimodal distribution of Fe isotope values (Fig. 6b), with two major peaks at $-1.5 \%$ and $0 \%$. Moreover, both nodules display a $\Delta^{33} \mathrm{~S}$ range from -1.5 to $+2.9 \%$ o (Fig. 6a), with two modes at $-1 \%$ and $+1.5 \%$. Nodule 1 shows also another mode at $+3 \%$. These Fe and $\mathrm{S}$ isotope distributions rule out any continuous process of pyrite nodule growth. The large ranges in isotopic composition could have been produced during either diagenesis or burial in association with fluid circulation. While metasomatic and/or metamorphic processes could fractionate both Fe and $\mathrm{S}$ isotopes, they cannot produce MIF of sulfur (e.g., Johnston, 2011). Moreover, textures of the pyrite nodules and hosting black shales suggest that these nodules were formed before burial compaction, and at the stage of early diagenesis. Furthermore, large range of $\Delta^{33} \mathrm{~S}$ values, from -1.5 to $+2.9 \%$, cannot be explained by equilibrium or kinetic dissolution-precipitation processes. Although redox processing of S may produce fractionations having a slightly different slope from that of the terrestrial fractionation 
line in the $\delta^{34} \mathrm{~S}$ vs. $\delta^{33} \mathrm{~S}$ space (Farquhar et al., 2010; Johnston, 2011), these processes cannot explain this range in $\Delta^{33} S$ values. Moreover, limited range of the $\delta^{34} S$ values observed in these nodules implies small deviation from terrestrial fractionation line due to biological sulphur processing (Canfield, 2001; Sim et al., 2011). Thus, this range of $\Delta^{33} \mathrm{~S}$ values can only be explained by different $\mathrm{S}$ sources that were present in the sediments, including the pyrite precursors themselves, diagenetic waters, or hydrothermal and metamorphic fluids. Whether those different $\mathrm{S}$ sources may also correspond to different $\mathrm{Fe}$ sources with distinct $\delta^{56} \mathrm{Fe}$ values requires thorough evaluation of diagenetic processes and pyrite formation pathways (Johnston, 2011). As the trend in $\mathrm{Fe}$ and $\mathrm{S}$ isotope composition is better defined for nodule 1, the following discussion will be mainly based on the results from this nodule.

Pyrite precipitation can be induced by both bacterial sulfate reduction (BSR) and dissimilatory iron reduction (DIR). Archer and Vance (2006) proposed that pyrite formed when these processes are coupled would display co-variation between $\delta^{56} \mathrm{Fe}$ and $\delta^{34} \mathrm{~S}$ values, however, we do not observe such relationship (Fig. 7). The absence of co-variation between $\delta^{56} \mathrm{Fe}$ and $\delta^{34} \mathrm{~S}$ values does not rule out microbial influence on pyrite formation, but suggests that nodules were not simply formed by sulfate and Fe(III) reduction in tandem.

Pyrite nodules in shales are thought to be formed by the dissolution of disseminated $\mathrm{Fe}$ sulfides present in the shale (Berner, 1984; Coleman and Raiswell, 1981; Kakegawa et al., 1998). The chemical reactions resulting in crystallization of pyrite are complex and involve, in addition to sulfate, sulfide, and Fe(II), several intermediate species such as thiosulfate, elemental sulfur, $\mathrm{FeS}$, and $\mathrm{Fe}_{3} \mathrm{~S}_{3}$ among others (see Rickard, 2013 for an extensive review). However experimental studies have suggested that pyrite can be easily formed from two different precursors, mackinawite, FeS, or greigite, $\mathrm{Fe}_{3} \mathrm{~S}_{4}$ (e.g., Rickard, 2013). Pyrite formation is 
kinetically controlled and requires iron loss from, or sulfur addition to, a pyrite precursor, which can be iron monosulfide, like $\mathrm{FeS}_{\mathrm{m}}$ (mackinawite), or iron polysulfide, like $\mathrm{Fe}_{3} \mathrm{~S}_{4}$ (greigite). In the case of mackinawite as a pyrite precursor, pyrite formation requires the presence of $\mathrm{H}_{2} \mathrm{~S}$ :

$$
\mathrm{FeS}_{m} \rightarrow \mathrm{FeS}_{a q}^{0}+\mathrm{H}_{2} \mathrm{~S}=\mathrm{FeS}_{2}+\mathrm{H}_{2}
$$

If greigite is the pyrite precursor, pyrite forms via a reaction between polysulfide and soluble FeS (Rickard and Luther, 2007). In the following, we will consider that pyrite nodules were formed from pyrite precursors, monosulfides and polysulfides.

\subsection{Origin of the isotopic variability in the core}

The core of nodule 1 shows a large S-MIF range of $2 \%$ and a positive co-variation between $\Delta^{33} S$ and $\delta^{34} S$ values (Fig. 4). The co-variation on the scale of the core of the pyrite nodule reflects $\mathrm{S}$ contribution from two different sources within the relatively small volume of hosting black shales. Although similar positive co-variation on the scale of the stratigraphically thick sedimentary sections has been linked to temporal changes in composition of atmospherically-derived sulphur-bearing aerosols (e.g., Farquhar and Wing, 2003; Kaufman et al., 2007; Ono et al., 2009), our in situ analyses of pyrite nodules indicate mixing of sulphur derived from two end-member sources hosted within a relatively small volume of black shale sediments deposited almost instantaneously on a geological timescale. Similar $\delta^{34} S-\Delta^{33} S$ trends have already been observed in Archean sedimentary pyrites (Ono et al. 2003, Farquhar et al. 2013) and has been explained by mixing between two compositionally distinct sources. These two sources are probably a monosulfide pyrite precursor $\left(\mathrm{FeS}_{\mathrm{m}}\right)$ and a fluid bearing $\mathrm{H}_{2} \mathrm{~S}$, according to the pyrite formation equation above. Both $\delta^{34} S$ and $\delta^{33} S$ values of the sources can be calculated from mass balance: 


$$
x_{F e S_{m}} \cdot \delta^{3 X} S_{F e S_{m}}+x_{H_{2} S} \cdot \delta^{3 X} S_{H_{2} S}=x_{\text {pyrite }} \cdot \delta^{3 X} S_{\text {pyrite }}
$$

where $\mathrm{X}$ is 3 or 4 , and the $\Delta^{33} \mathrm{~S}$ value is then calculated from the $\delta^{34} \mathrm{~S}$ and $\delta^{33} \mathrm{~S}$ values and $x$ is the proportion of total $\mathrm{S}$ in the different $\mathrm{S}$ species, such as $\mathrm{FeS}_{\mathrm{m}}, \mathrm{H}_{2} \mathrm{~S}$, and pyrite. In our case, $x_{\text {pyrite }}=x_{\mathrm{FeSm}}+x_{\mathrm{H} 2 \mathrm{~S}}$. The $\delta^{34} \mathrm{~S}$ values of $\mathrm{FeS}_{\mathrm{m}}$ and $\mathrm{H}_{2} \mathrm{~S}$ reflect the isotopic composition of $\mathrm{H}_{2} \mathrm{SO}_{4}$ and $\mathrm{S}_{8}$ aerosols, respectively, as further discussed below.

Two end-members can be defined to reproduce the $\delta^{34} \mathrm{~S}$ and $\delta^{33} \mathrm{~S}$ relationships, one with negative $\Delta^{33} \mathrm{~S}$ and unfractionated $\delta^{34} \mathrm{~S}$ values and the other one with $\delta^{34} \mathrm{~S}$ values ranging from +1.8 to $+8 \%$ and $\Delta^{33} \mathrm{~S}$ values close to $+0.6 \%$. With these two end-members, almost all $\mathrm{S}$ isotope compositions of the cores of both nodules can be reproduced (Fig. $4 \mathrm{~b}$ ). $\mathrm{H}_{2} \mathrm{SO}_{4}$ aerosols are formed in the atmosphere and delivered to the ocean, and $\mathrm{H}_{2} \mathrm{SO}_{4}$ is preferentially processed in the water column to form $\mathrm{H}_{2} \mathrm{~S}$ with negative $\Delta^{33} \mathrm{~S}$ values. $\mathrm{H}_{2} \mathrm{~S}$ can then react with $\mathrm{Fe}$ in the water column to form small particles of iron monosulfide, such as mackinawite (Rickard and Luther, 2007), which would record the negative S-MIF of the sulfur source. During early diagenesis in sediments, mackinawite would dissolve contributing to the growth of larger pyrite nodules by Ostwald ripening effect (cf. Kakegawa et al., 1998). Elemental sulfur with positive $\Delta^{33} \mathrm{~S}$ values that was also produced via photochemical reactions in oxygen-free atmosphere was preferentially delivered to the sediments rather than utilized in the water column as $S_{8}$ is insoluble (Rickard, 2013) and its biological intake and processing in the Archean, oxygen-free ocean would be slower than that of dissolved sulfate. In pore waters, $\mathrm{S}_{8}$ rings would be gradually open and sulfur chains and compounds would be biologically converted to $\mathrm{H}_{2} \mathrm{~S}$. Various microbial organisms are able to disproportionate elemental sulfur in the sediments and promote pyrite formation (e.g., Johnston 2011). Thus the core of the pyrite nodule was formed by mixing 
of sulfur derived from the dissolution of the mackinawite and elemental sulfur present in sediment pore waters.

Crystallization of pyrite forming the nodule core and resulting from the dissolution of mackinawite can be modelled as a Rayleigh distillation process to explain the Fe isotope variations across the nodule core. In this model, the $\delta^{56} \mathrm{Fe}$ value of each increment of precipitated pyrite is controlled by the isotopic fractionation between dissolved $\mathrm{FeS}_{\mathrm{m}}$ and $\mathrm{FeS}_{2}$ ( $\left.\Delta_{\text {pyrite-FeSm dissolved }}\right)$ and by the evolving composition of the fluid, which is controlled by the fraction $(f)$ of $\mathrm{FeS}_{\mathrm{m}}$ remaining in solution:

$$
\delta^{56} F e_{\text {pyrite }}=\delta^{56} \mathrm{Fe}\left(\mathrm{FeS} \mathrm{S}_{m} \text { dissolved }\right)^{i}+\Delta_{\text {pyrite-FeS } \text { dissolved }} \times(1+\ln f)
$$

For this calculation, we adopt an isotopic fractionation factor $\left(\Delta_{\text {pyrite-FeSm dissolved }}\right)$ of $-1 \%$ o for pyrite formation according to theoretical calculations (Polyakov et al., 2007; Polyakov and Soultanov, 2011) and recent experiments (Guilbaud et al., 2011). Rayleigh fractionation can explain the $\delta^{56} \mathrm{Fe}$ distribution for the core of nodule 1 by near total consumption of dissolved $\mathrm{FeS}_{\mathrm{m}}$ (Fig. 8). Considering a fluid with an initial $\delta^{56} \mathrm{Fe}$ value of $-1.2 \%$ and for $f$ from 1 to 0.08 , the calculated $\delta^{56} \mathrm{Fe}_{\text {pyrite }}$ values range from -2.2 to $+1.78 \%$, which is in agreement with the measured range (from -2.11 to $+0.45 \%$ ). Thus, the cores of the pyrite nodules could have formed in a closed with respect to Fe pore-water system with iron supplied by the dissolution of a mackinawite in the sediments. This result also implies that the rim was also formed under similar Fe-limited pore-water conditions. Assuming that the mackinawite dissolution produced a pore water fluid with negative $\delta^{56} \mathrm{Fe}$ value of approximately $-1.2 \%$, reflecting the average $\mathrm{Fe}$ isotope composition of the mackinawite, and using the experimentally-determined Fe isotope equilibrium fractionation factor between mackinawite and $\mathrm{Fe}(\mathrm{II})$ of around $-0.3 \%$ at $25^{\circ} \mathrm{C}$ 
(Butler et al., 2005; Guilbaud et al., 2011), the mackinawite in the water column should have crystallized from a source with $\delta^{56} \mathrm{Fe}$ value $\approx-0.9 \%$.

We infer that the core of the pyrite nodule formed during early diagenesis by the dissolution of mackinawite, which would have had negative $\delta^{56} \mathrm{Fe}$ values, near to $0 \%$ o $\delta^{34} \mathrm{~S}$ values, and negative $\Delta^{33} \mathrm{~S}$ values. Such a pyrite precursor could have formed in an aqueous solution, possibly in the water column or at the water-sediment interface. The negative $\delta^{56} \mathrm{Fe}$ value of $\mathrm{FeS}_{\mathrm{m}}$ reflects composition of dissolved $\mathrm{Fe}(\mathrm{II})$ depleted in heavy isotopes. In principle, such Fe isotope composition can be produced via two main pathways: (i) DIR during diagenesis releasing $\mathrm{Fe}(\mathrm{II})$ depleted in heavy isotopes $\left(\delta^{56} \mathrm{Fe} \approx-2 \%\right.$ ) into pore water, which is transferred to pyrite precursor by precipitation, as in modern anoxic environments (Johnson et al., 2008; Johnson et al., 2004; Percak-Dennett et al., 2011; Severmann et al., 2006), and (ii) oxidation to $\mathrm{Fe}(\mathrm{III})$ and precipitation of Fe-oxyhydroxides during iron cycling in the water column producing a residual Fe(II) pool depleted in heavy isotopes (Rouxel et al., 2008; Rouxel et al., 2005; Tsikos et al., 2010). The presence of negative S-MIF indicates that the mackinawite was formed by sulfate reduction, likely close to the water-sediment interface, where both DIR and partial iron oxidation processes are possible and could explain the negative $\delta^{56} \mathrm{Fe}$ values. In the case of DIR, pore waters should have had a negative $\delta^{56} \mathrm{Fe}$ value of approximately $-1 \%$ o to explain the isotopic composition of the pyrite precursor. Although it is known that pore waters near the seawater-sediment interface in modern marine settings can have $\delta^{56} \mathrm{Fe}$ values down to $-3.4 \%$ in some extreme cases (Homoky et al., 2009; Rouxel et al., 2008; Severmann et al., 2006), more typically they display an average value around $0 \%$ in anoxic environments (Severmann et al., 2006). The second pathway suggests that large-scale seawater redox cycling could be responsible for the origin of negative $\delta^{56} \mathrm{Fe}$ values of pyrite precursor (Planavsky et al., 2012; 
Rouxel et al., 2005). The preferential sequestration of heavy Fe isotopes into Fe-oxyhydroxides would produce an isotopically negative Fe(II) pool. This pathway assumes that the pyrite precursor with negative $\delta^{56} \mathrm{Fe}$ values reflects the presence of an isotopically light reservoir in the water column. Evidence for this process is found in the Fe isotope composition of magnetite and hematite in iron formations, which are typically characterized by positive $\delta^{56} \mathrm{Fe}$ values (Johnson et al., 2003; Planavsky et al., 2012). Although it still remains largely unresolved whether precipitation of Fe oxyhydroxides (cf., Rouxel et al., 2005) or iron-shuttle from continental margins to deep-waters, driven by dissimilatory iron reduction (Severmann et al., 2006; Severmann et al., 2008) was a major control over Fe isotope composition of seawater, both processes would contribute to negative Fe isotope composition of seawater. The pyrite precursor of the nodule core, mackinawite, was thus formed in the water column by sulfate reduction, as indicated by S-MIF, and from a dissolved iron pool with negative $\delta^{56} \mathrm{Fe}$ values.

\subsection{Origin of the isotopic composition of the rim}

The nodule rims display different $\mathrm{Fe}$ and $\mathrm{S}$ isotope compositions from their cores and a coarse-grained texture, clearly indicating distinct history from the cores. First and foremost, the

rim has $\delta^{56} \mathrm{Fe}$ values close to $0 \%$ and mostly positive $\Delta^{33} \mathrm{~S}$ values, the latter suggestive of a sulfur source derived from $\mathrm{S}_{8}$ aerosols. Elemental sulfur is highly insoluble and less amenable to biological processes; as a result, most of it is transferred to sediments as solid S (Ono et al., 2003a). Pyrite cannot form directly from elemental solid S (Rickard and Luther, 2007), which implies an intermediate step to break the $S_{8}$ rings (Rickard, 2013) and react with a dissolved pyrite precursor. Elemental solid S can react with dissolved mackinawite present in the sediment pore waters to form greigite as described in the following equation: 


$$
3 \mathrm{FeS}_{m}+\mathrm{S}^{0}=\mathrm{Fe}_{3} \mathrm{~S}_{4}
$$

Greigite can form directly from mackinawite in anoxic and acidic environments, in which low $\mathrm{pH}$ enhances the dissolution of mackinawite (Rickard and Luther, 2007). Greigite formation from mackinawite can also be promoted by sulfate-reducing bacteria (Rickard and Luther, 2007). If pyrite precursor, greigite, was formed during an early stage of diagenesis, when the mackinawite was still present in the sediment, by the reduction of the $S_{8}$ in a highly reducing fluid (e.g., due to the presence of carbonaceous matter), then the variations in $\Delta^{33} S$ composition of the pyrite nodule rim must be due to mixing between $\mathrm{S}$ from $\mathrm{FeS}_{\mathrm{m}}$ and $\mathrm{S}^{0}$ sources. With respect to Fe isotope values, pyrite nodule rims may reflect mixing between negative Fe isotope values of mackinawite and pore water fluid, derived from dissolution of reactive iron in sediments, e.g., Fe-oxyhydroxides. Thus, pyrite nodule rims could have been formed by the dissolution of the same mackinawite as the nodule cores in contact with a reducing fluid in sediments containing elemental sulfur. Different composition of cores and rims suggests that the mackinawite dissolution started earlier in the diagenesis and, subsequently, overlapped in time with the dissolution of elemental sulfur. That is why the inner part of the rim has still negative $\Delta^{33} \mathrm{~S}$ values, largely inherited from the mackinawite, gradually giving away to positive $\Delta^{33} \mathrm{~S}$ values, derived from the elemental sulphur, towards the outer part of the rim.

Complicating this picture further are trace element zonation patterns and petrographic observations. The rim has a coarse-grained texture associated with nickel depletion and cobalt enrichment, suggesting its growth during burial diagenesis or in association with postdepositional processes such as metasomatism (Large et al., 2009; Steadman et al., 2013). In this case, the fluid should have carried sulfur with positive MIF-S as observed on the rims, which implies that either the fluid had an access to an atmospheric source or was enriched in sulfur by 
dissolution of sulfides bearing MIF-S. The rim pyrite has different $\mathrm{S}$ and Fe isotope composition from that of the core of the pyrite nodule and thus, by extension, from that of the core pyrite precursor, mackinawite. The most parsimonious scenario is that the pyrite rim was formed by the dissolution of the small, disseminated greigite grains during burial. In this case, the trace element composition of the rim was acquired from the late diagenetic or metasomatic fluids different in trace element composition from the early diagenetic fluids, while the $\mathrm{Fe}$ and $\mathrm{S}$ isotope compositions of the rim reflect the pyrite precursor, i.e., greigite, and reactive iron in sediments. Disseminated pyrite could have also formed from the disseminated greigite precursor. It would be useful to test this hypothesis by analyzing individual disseminated pyrite grains, however their small size (around $2 \mu \mathrm{m}$ ) precludes this approach.

\subsection{Nodule formation model and paleoenvironmental implications}

Pyrite nodules were formed from two different precursors, mackinawite and greigite, which have recorded different environmental conditions. Mackinawite formed in the water column from the sulfate pool and provides constraints about this environment, while greigite formed in the sediment via reaction of mackinawite with atmospherically-derived elemental sulfur that was present in the sediment pore-waters and records late-stage diagenetic and/or burial conditions. Mackinawite crystallized from sulfide likely produced by BSR and from dissolved iron (Fig 9a), suggesting an Fe-rich deep water, whereas greigite was formed from dissolved mackinawite and elemental sulfur in pore waters (Fig 9b). The pyrite nodule core was formed by the dissolution of mackinawite in a closed system with a limited-size Fe reservoir and by mixing of sulfur derived from the pyrite precursor, mackinawite, and elemental sulfur in the pore water (Fig 9a). At some point, mackinawite was consumed and the sediment contained 
excess of elemental sulfur. Some of the remaining mackinawite present in sediments reacted in a solid state with elemental sulfur to form small disseminated greigite crystals (Fig. 9b). During burial at a higher temperature and in the presence of the late-stage diagenetic or metasomatic fluid, the disseminated greigite grains started to dissolve aggregating into coarse-grained pyrite nodule rims and forming small, disseminated pyrite grains in the sediment (Fig. 9c). The diagenetic realm had limited Fe pool derived from mackinawite and reactive iron in sediments, which experienced continuous Rayleigh distillation during the growth of pyrite nodule from the centre to the rim, and at least two S sources, which were partially segregated into the pyrite nodule core and rim.

The $\delta^{56} \mathrm{Fe}$ and $\delta^{34} \mathrm{~S}$ isotope values do not show co-variation (Fig. 7) previously inferred for the Belingwe sulfides (Archer and Vance, 2006), challenging the notion of coupled S and Fe reduction. Furthermore, while Fe isotope values become progressively more positive towards the rim and can be explained by Rayleigh distillation in the closed diagenetic system with respect to $\mathrm{Fe}, \delta^{34} \mathrm{~S}$ values do not show any systematic trend from the core to the rim. As a result, our data is consistent with the diagenetic setting limited with respect to Fe, but unlimited with respect to S. The rims are clearly formed after the core, but still likely with $\mathrm{S}$ source hosted in the same sedimentary package as evidenced by the presence of MIF in S isotopes. Considering high organic carbon loading in this setting, Fe reduction would have been quantitative and Fe isotope fractionations during dissimilatory Fe reduction should not be expressed. These observations rule out the model proposed by Archer and Vance (2006) based on coupled Fe and $S$ reduction. Furthermore, we inferred highly fractionated by precipitation of Fe-oxyhydroxides seawater based on the average Fe isotope values of the cores of the pyrite nodules $(-1.7 \pm 0.3 \%$ o for nodule 1 and $-1.1 \pm 0.5 \%$ for nodule 2 ), equilibrium $\mathrm{Fe}$ isotope fractionation during 
precipitation of mackinawite (-0.3 to $-0.9 \%$; Butler et al., 2005; Guilbaud et al., 2011), and possible range of $\delta^{56} \mathrm{Fe}$ values of the $\mathrm{Fe}$ sources to the Archean seawater ( 0.0 to $-0.5 \%$; Rouxel et al., 2005). We concur with Guilbaud et al. (2001) that pyrite can be formed by the Rayleigh distillation process based on a partial $\mathrm{Fe}(\mathrm{II})_{\mathrm{aq}}$ utilization during abiotic pyrite precipitation. In situ analysis is a relevant approach to test this model. However, we did not observe the highly fractionated $\mathrm{Fe}$ isotope values predicted by the model. Instead, the Rayleigh distillation modelling of the fractionated $\mathrm{Fe}$ isotope compositions of the cores of our nodules reflects the almost total Fe-utilization in a closed system. We therefore infer that the highly fractionated, average $\mathrm{Fe}$ isotope composition of the cores of the pyrite nodules corresponds to the Fe isotope composition of seawater. Rouxel et al. (2005) proposed that negative Fe isotope values of bulk pyrite nodules in Archean organic matter-rich shales reflect composition of Archean seawater influenced by Fe-oxyhydroxide precipitation. Our study also shows micro-scale Fe isotope heterogeneity within pyrite nodules reflecting fractionations in the diagenetic realm.

The nodules display S-MIF with both positive and negative values, which suggest the presence of two distinct sulfur pools in the diagenetic realm; one being mackinawite derived from soluble sulfate and the other being less reactive pool of insoluble, atmospherically-derived elemental sulfur as already proposed by Farquhar et al. (2013). Importantly, these well-defined S sources were not entirely mixed on a micrometer-scale to erase their distinct $\mathrm{S}$ isotope signatures during S processing in sediment pore-waters. We relate this unique preservation of atmospheric $\mathrm{S}$ signature during diagenetic processing to the difference in reactivity between these two pools with the insoluble sulfur compounds derived from atmospheric elemental sulfur being less reactive with respect to the seawater sulfate. Fe and S isotope variations observed in the Archean pyrite nodules reflect the contribution of two atmospherically-derived $\mathrm{S}$ sources and Fe pool 
fractionated by precipitation of iron oxyhydroxides as well by diagenetic processes involved in the growth of pyrite nodules.

\section{Conclusions}

In situ coupled Fe and $\mathrm{S}$ isotope study of the c. $2.7 \mathrm{Ga}$ pyrite nodules have revealed an extreme isotopic variability both in Fe and $\mathrm{S}$ at the micrometer scale. It has been shown for the first time that these nodules have both positive and negative $\Delta^{33} \mathrm{~S}$ values and highly variable $\mathrm{Fe}$ isotope composition. They reveal a complex crystallization history with, at least, two steps of dissolution and precipitation of two different pyrite precursors involved in the Ostwald ripening process. The core of the pyrite nodules has grown by dissolution of fine-grained mackinawite precipitated in the water column, while the rims were formed during the late diagenesis by dissolution of disseminated greigite grains crystallized during early diagenesis, when remaining dissolved $\mathrm{FeS}_{\mathrm{m}}$ clusters reacted with broken $\mathrm{S}_{8}$ rings. The nodules thus record $\mathrm{S}$ processing in two different environments, water column and sediment pore-waters, at the time when the Earth's atmosphere was still anoxic. They also indicate the presence of two distinct and yet contemporaneous seawater sulfur pools derived from the atmosphere, soluble sulfate and insoluble elemental sulfur, which, being different in their isotopic composition, are now resolvable at a micrometer-scale within the pyrite nodules. It also implies that temporal trends in $\Delta^{33} \mathrm{~S}$ values earlier inferred from bulk-rock $\mathrm{S}$ isotope analyses showing positive co-variation between $\Delta^{33} S$ and $\delta^{34} S$ values (e.g., Kaufman et al., 2007; Ono et al., 2009) represent local variations in relative contribution of these two atmospherically-derived S sources and cannot be reliably used for global correlation of hosting sedimentary successions. 
This study, based on two isotopic systems, reveals that pathways for pyrite nodule formation are complex and involve several pyrite precursors, such as mackinawite and greigite, and isotopically distinct $\mathrm{S}$ and Fe sources. However, the isotopic and elemental records spatially preserved in these pyrite nodules do constrain the conditions for the precipitation of pyrite precursors and thus can be used as proxies for paleoenvironmental conditions in the Archaen oceans and atmosphere. The study also illustrates the importance of in situ and coupled isotopic studies to reveal diagenetic histories and pyrite formation pathways.

Acknowledgements: Frantz Ossa Ossa is thanked for assistance with trace element analysis by x-ray diffraction. Vincent Busigny and Jabrane Labidi (IPGP, Paris) are thanked for fruitful discussions. Caroline Guillemette (CRPG, Nancy) is thanked for the measurements of S isotopic composition of Spain pyrite. Participation by AB was supported by NSERC Discovery Grant. The UCLA ion microprobe facility is partially supported by a grant from the NSF Instrumentation and Facilities program.

Table 1: Fe and $\mathrm{S}$ isotopic compositions of both nodules. The errors are given in 1 sigma. n.a. refers to not analyzed. 
Table 1

Fe and $\mathrm{S}$ isotopic compositions of both nodules. The errors are given in 1 sigma. n.a. refers to not analyzed.

\begin{tabular}{|c|c|c|c|c|c|c|c|c|c|}
\hline & & Analyses & $\begin{array}{l}\text { Distance } \\
(\mathrm{mm})\end{array}$ & $\begin{array}{l}\delta^{34} S \\
(\%)\end{array}$ & $\begin{array}{l}\delta^{34} S \text { err } \\
(\%)\end{array}$ & $\begin{array}{l}\Delta^{33} S \\
(\%)\end{array}$ & $\begin{array}{l}A^{33} S \text { err } \\
(\% 0)\end{array}$ & $\begin{array}{l}8^{56} \mathrm{Fe} \\
(\%)\end{array}$ & $\begin{array}{l}8^{56} \mathrm{Fe} \text { err } \\
(\% 0)\end{array}$ \\
\hline \multirow[t]{23}{*}{ Nodule 1} & & AH-sample9-pt@1 & 6888 & 3.93 & 0.33 & -0.37 & 0.03 & 0.45 & 0.22 \\
\hline & & AH-sample9-pt@02 & 6686 & 4.81 & 0.33 & 1.20 & 0.03 & -0.10 & 0.22 \\
\hline & & AH-sample9-pt@03 & 6388 & 3.41 & 0.33 & -0.90 & 0.03 & -1.19 & 0.22 \\
\hline & & AH-sample9-pt@04 & 6086 & 3.10 & 0.33 & 2.89 & 0.03 & -0.19 & 0.23 \\
\hline & & AH-sample9-pt@05 & 5788 & 2.58 & 0.33 & 1.22 & 0.03 & -1.60 & 0.24 \\
\hline & & AH-sample9-pt@06 & 5486 & 2.05 & 0.34 & -1.28 & 0.03 & -1.95 & 0.23 \\
\hline & & AH-sample9-pt@07 & 5088 & -0.55 & 0.33 & -0.67 & 0.03 & -2.11 & 0.22 \\
\hline & \multirow[t]{7}{*}{ Rim } & AH-sample9-pt@08 & 4786 & 2.91 & 0.34 & -1.14 & 0.03 & -1.92 & 0.23 \\
\hline & & AH-sample9-pt@09 & 4488 & 4.03 & 0.33 & -0.84 & 0.03 & n.a. & n.a. \\
\hline & & AH-sample9-pt@10 & 4186 & 4.83 & 0.33 & -0.30 & 0.03 & -1.99 & 0.23 \\
\hline & & AH-sample9-pt@11 & 3888 & 4.11 & 0.33 & -0.38 & 0.03 & -1.39 & 0.22 \\
\hline & & AH-sample9-pt@12 & 3586 & 3.92 & 0.34 & -0.71 & 0.03 & -1.92 & 0.23 \\
\hline & & AH-sample9-pt@13 & 3288 & 4.31 & 0.33 & 0.59 & 0.03 & -1.76 & 0.22 \\
\hline & & AH-sample9-pt@14 & 2986 & 2.43 & 0.34 & -0.82 & 0.03 & -1.79 & 0.23 \\
\hline & \multirow[t]{6}{*}{ Core } & AH-sample9-pt@15 & 2688 & 2.98 & 0.34 & -0.99 & 0.03 & -1.53 & 0.22 \\
\hline & & AH-sample9-pt@16 & 2386 & 1.98 & 0.33 & -1.29 & 0.03 & -1.36 & 0.22 \\
\hline & & AH-sample9-pt@17 & 2088 & 0.83 & 0.34 & -1.47 & 0.03 & -1.16 & 0.22 \\
\hline & & AH-sample9-pt@18 & 1786 & 2.22 & 0.34 & 0.23 & 0.03 & -1.17 & 0.22 \\
\hline & & AH-sample9-pt@19 & 1488 & 0.64 & 0.34 & -0.20 & 0.03 & -0.25 & 0.21 \\
\hline & & AH-sample9-pt@20 & 1186 & 2.94 & 0.34 & 1.41 & 0.03 & -0.14 & 0.22 \\
\hline & \multirow{3}{*}{ Rim } & AH-sample9-pt@21 & 888 & 3.84 & 0.33 & 0.31 & 0.03 & -0.67 & 0.21 \\
\hline & & AH-sample9-pt@22 & 586 & n.a. & n.a. & n.a. & n.a. & -0.61 & 0.21 \\
\hline & & AH-sample9-pt@23 & 288 & 2.96 & 0.34 & 2.47 & 0.03 & -0.29 & 0.21 \\
\hline \multirow[t]{23}{*}{ Nodule 2} & \multirow{9}{*}{ Rim } & sample9-pt@1 & 0 & 2.26 & 0.16 & -1.62 & 0.03 & -0.11 & 0.22 \\
\hline & & sample9-pt@02 & 202 & 1.81 & 0.18 & 1.36 & 0.03 & n.a. & n.a. \\
\hline & & sample9-pt@03 & 357 & 2.39 & 0.17 & 0.90 & 0.03 & -0.27 & 0.22 \\
\hline & & sample9-pt@04 & 533 & 4.85 & 0.18 & 1.95 & 0.03 & 0.75 & 0.22 \\
\hline & & sample9-pt@05 & 836 & 2.51 & 0.15 & 1.81 & 0.03 & n.a. & n.a. \\
\hline & & sample9-pt@06 & 1006 & 7.76 & 0.17 & -1.33 & 0.03 & -0.73 & 0.22 \\
\hline & & sample9-pt@07 & 1237 & 5.66 & 0.17 & -0.09 & 0.03 & n.a. & n.a. \\
\hline & & sample9-pt@08 & 1411 & 0.73 & 0.15 & -1.34 & 0.03 & -0.42 & 0.22 \\
\hline & & sample9-pt@09 & 1606 & 1.82 & 0.18 & 1.06 & 0.03 & n.a. & n.a. \\
\hline & \multirow[t]{7}{*}{ Core } & sample9-pt@10 & 1819 & 4.02 & 0.15 & -0.11 & 0.03 & -0.38 & 0.22 \\
\hline & & sample9-pt@11 & 1995 & 1.91 & 0.16 & -0.74 & 0.03 & n.a. & n.a. \\
\hline & & sample9-pt@12 & 2204 & 0.59 & 0.18 & -0.90 & 0.03 & n.a. & n.a. \\
\hline & & sample9-pt@13 & 2396 & 1.30 & 0.17 & -1.19 & 0.03 & -1.08 & 0.22 \\
\hline & & sample9-pt@14 & 2618 & 0.94 & 0.16 & -0.41 & 0.03 & -1.58 & 0.22 \\
\hline & & sample9-pt@15 & 2828 & 1.92 & 0.16 & -0.52 & 0.03 & -1.53 & 0.22 \\
\hline & & sample9-pt@16 & 3010 & 2.25 & 0.16 & -0.40 & 0.03 & -0.79 & 0.22 \\
\hline & \multirow[t]{7}{*}{ Rim } & sample9-pt@17 & 3232 & 0.56 & 0.18 & -1.35 & 0.03 & -0.30 & 0.21 \\
\hline & & sample9-pt@18 & 3403 & 1.50 & 0.18 & -1.28 & 0.03 & -0.45 & 0.22 \\
\hline & & sample9-pt@19 & 3635 & 0.36 & 0.17 & -1.21 & 0.03 & -0.01 & 0.22 \\
\hline & & sample9-pt@20 & 4032 & 1.60 & 0.15 & -0.51 & 0.03 & n.a. & n.a. \\
\hline & & sample9-pt@21 & 4219 & 8.20 & 0.16 & 1.14 & 0.03 & n.a. & n.a. \\
\hline & & sample9-pt@22 & 4419 & 3.49 & 0.16 & -0.13 & 0.03 & n.a. & n.a. \\
\hline & & sample9-pt@23 & 4524 & 1.57 & 0.18 & -0.67 & 0.03 & n.a. & n.a. \\
\hline
\end{tabular}

Figure 1: Photomicrographs (reflected light) of pyrite textures. A. Ellipsoidal pyrite nodule. B. Portion of pyrite nodule with rim and irregular central domain of recrystallized pyrite. $\mathbf{C}$. Disseminated pyrite in shale matrix near pyrite nodule. D. Portion of B showing finely intergrown pyrite and matrix silicates of nodule centre, recrystallized pyrite rim and disseminated pyrite in shale matrix. E. Pyrite lamina in shale showing recrystallized rim with chalcopyrite (arrows). F. Disseminated pyrite within nodular structure. G. Portion of pyrite nodule with coarse pyrite present in pressure shadow (top right). H. Same as G showing chalcopyrite inclusions (arrows). 

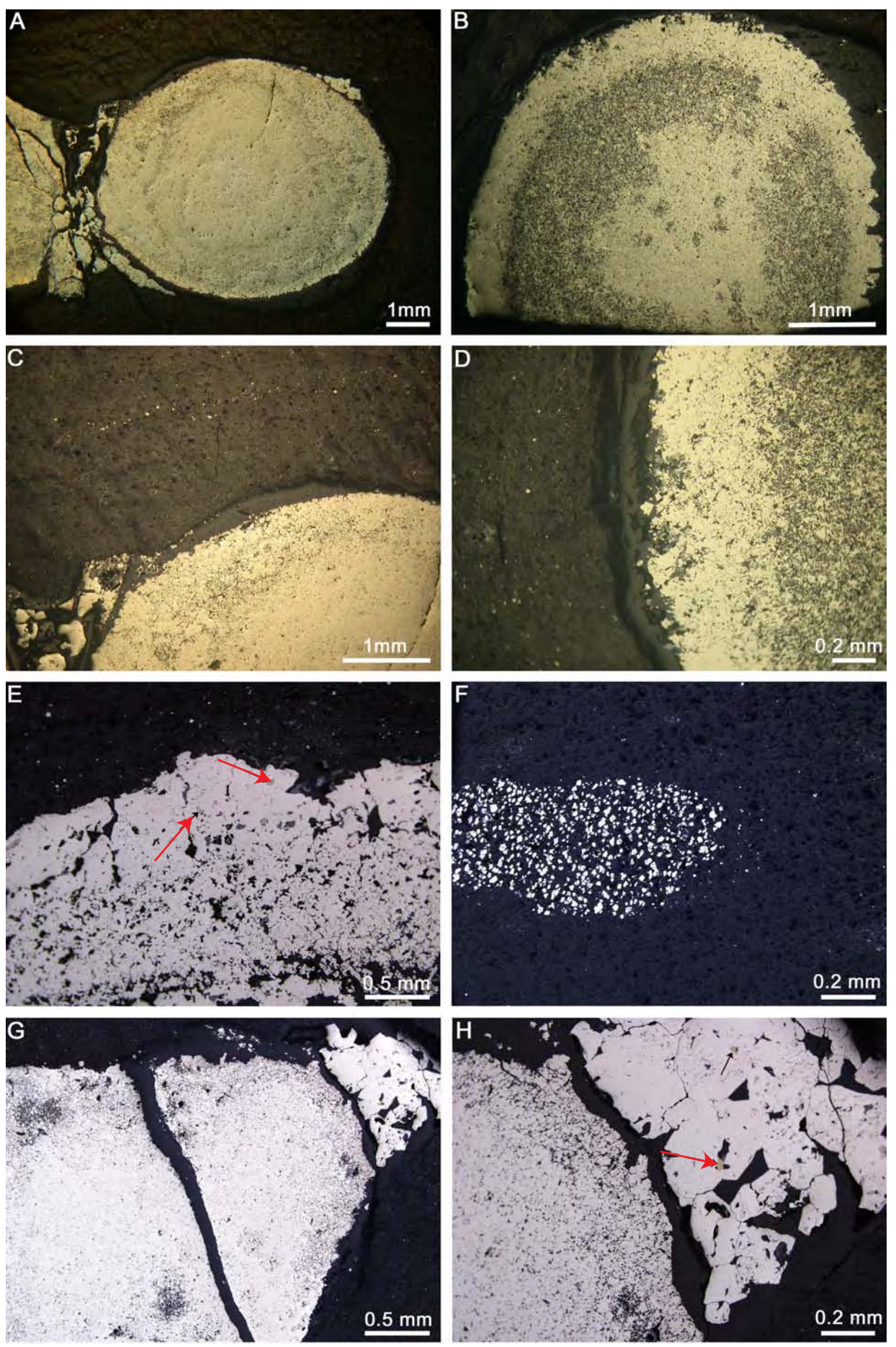

Figure 2: a. Scanning electron microscopy (SEM) images of the polished surface of the investigated pyrite nodules. The white dots indicate the in situ $\mathrm{Fe}$ and $\mathrm{S}$ isotope and trace element spot analyses. b. The Co and Ni concentration (wt. \%, EPMA) profile of nodule 1 
shows difference between the coarse-grained rim and the fine-grained core (see text for the definition of core and rim). c. A SEM image of the core-rim transition zone showing textural difference.

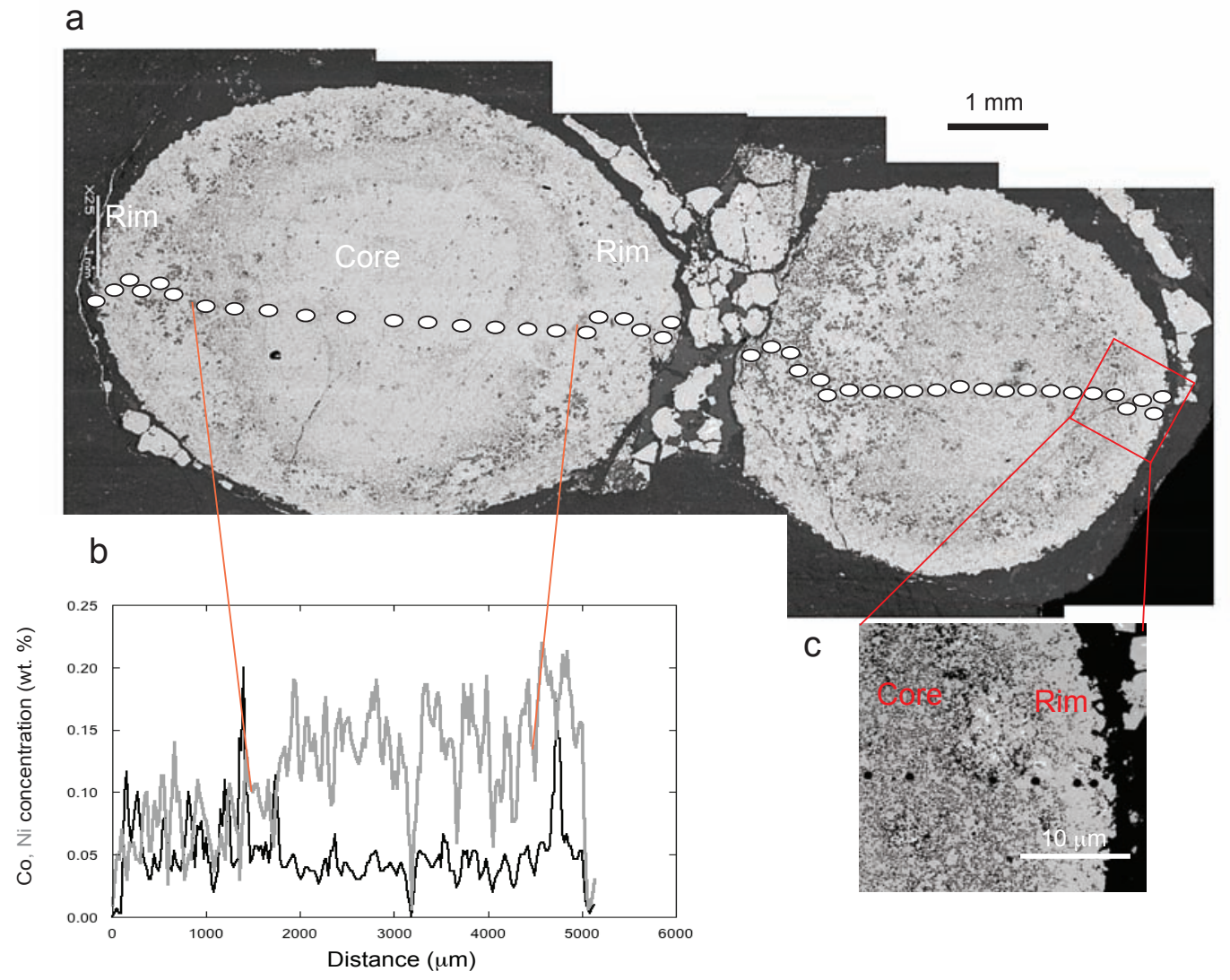

Figure 3: $\delta^{56} \mathrm{Fe}(\mathrm{a}, \mathrm{b}), \delta^{34} \mathrm{~S}(\mathrm{c}, \mathrm{d})$ and $\Delta^{33} \mathrm{~S}(\mathrm{e}, \mathrm{f})$ profiles across the pyrite nodule 1 (circles) and nodule 2 (squares). Both nodules reveal large, micrometer-scale isotopic heterogeneity, but nodule 1 shows more clearly defined trends in isotopic composition from the centre to the rim. The error bars are comprised in the symbols. Note that the textural boundary between the core and the rim does not exactly match the change in isotopic composition, especially for the $\Delta^{33} \mathrm{~S}$ values. 

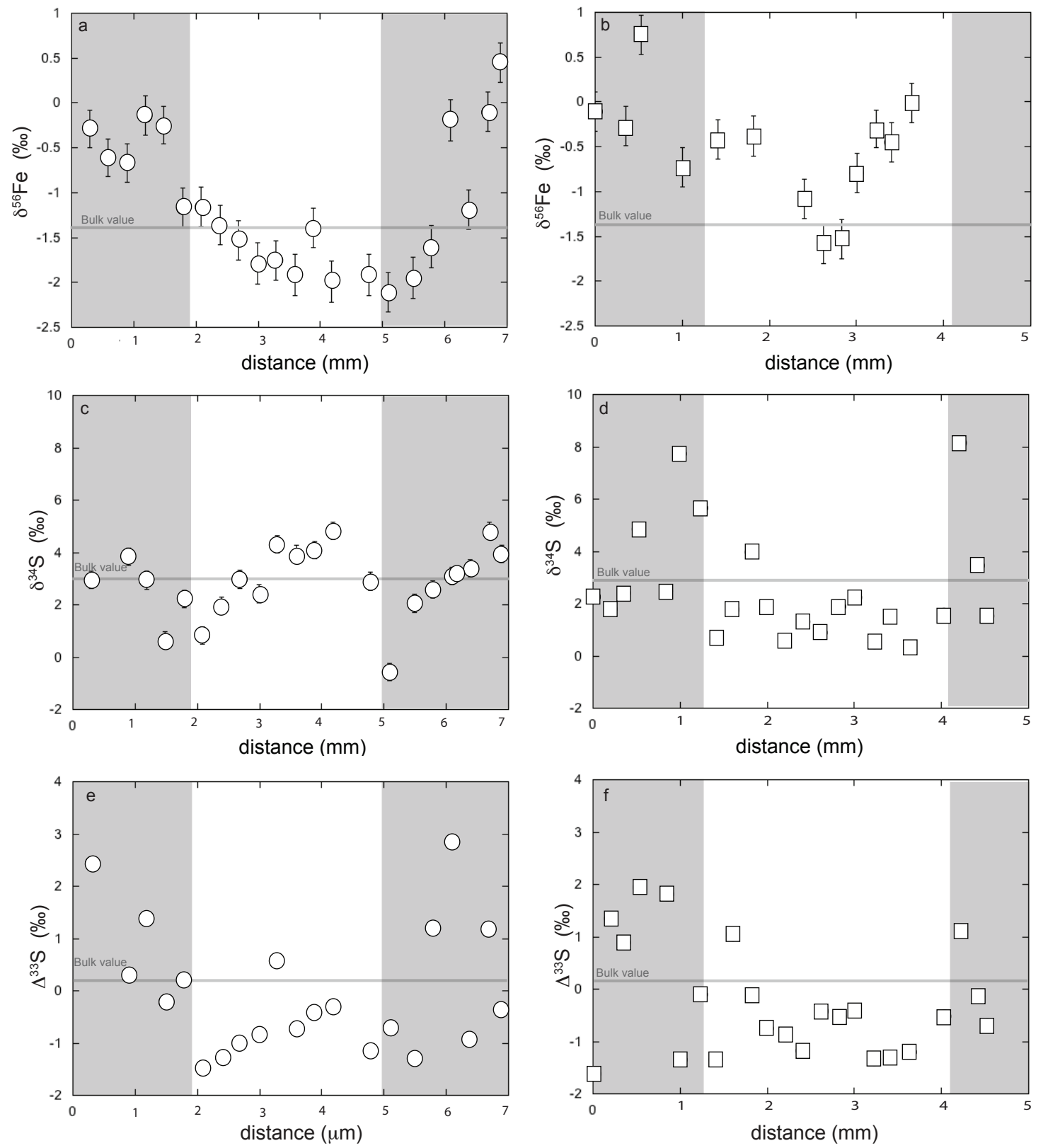

Figure 4: $\delta^{34} S$ and $\Delta^{33} S$ variations of (a) cores (white) and rims (grey) of both nodules and (b) cores of nodule 1 (circles) and nodule 2 (squares). Possible end-members (see text for further 
discussion) are represented by stars (white for sulfate aerosols and black for elemental sulfur aerosols). Note that the elemental sulfur end-member has a range of $\delta^{34} \mathrm{~S}$ values.
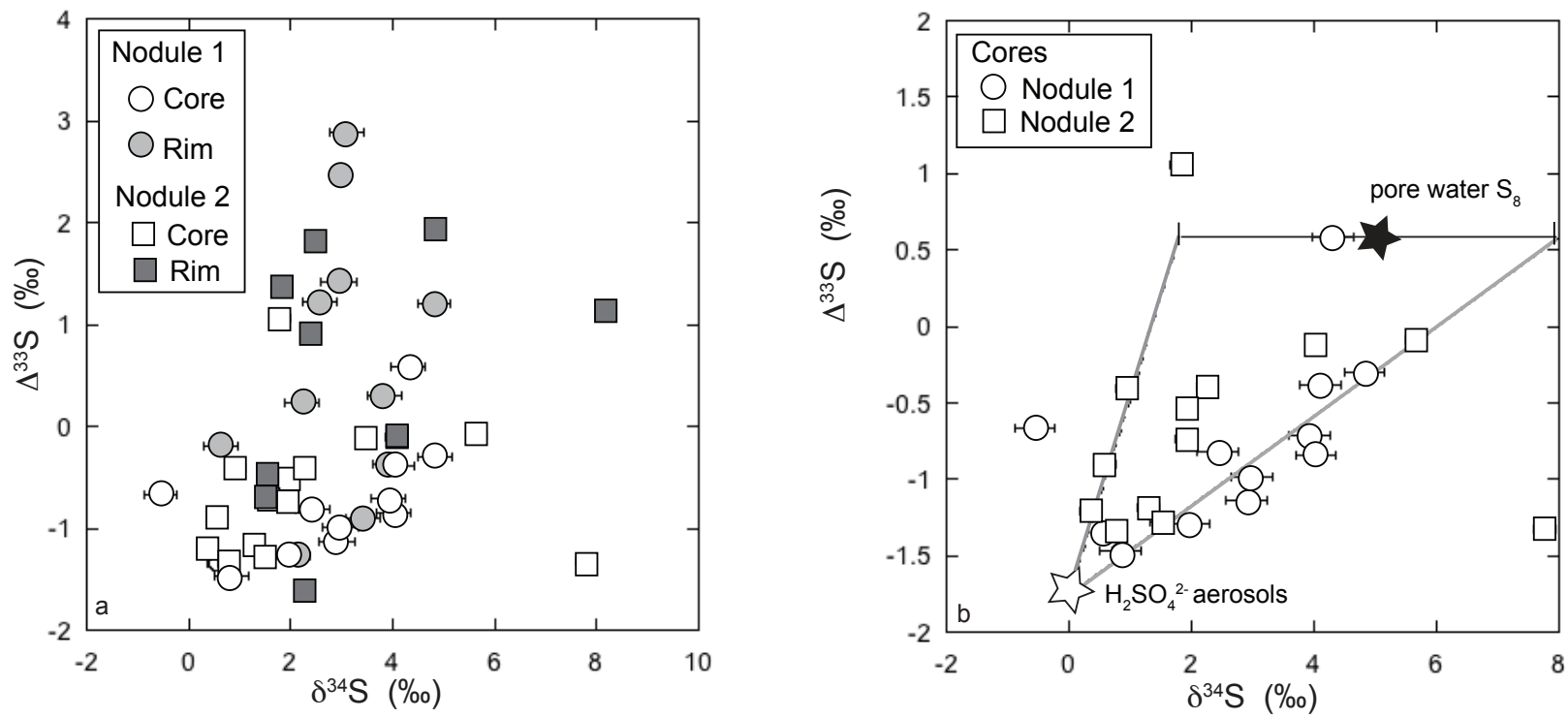

Figure 5: $\delta^{56} \mathrm{Fe}$ and $\Delta^{33} \mathrm{~S}$ values for nodule 1 (a) and nodule 2 (b).
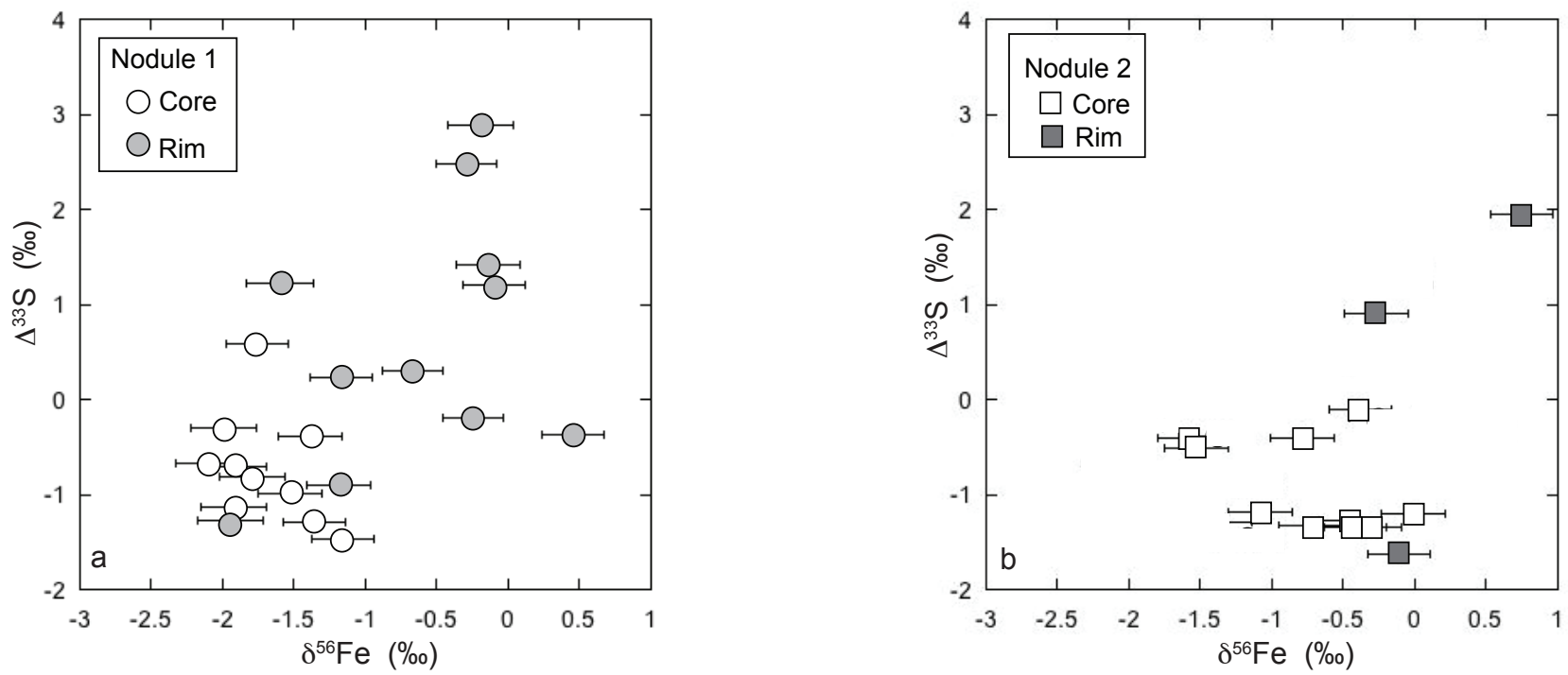
Figure 6: Histogram of $\Delta^{33} \mathrm{~S} \Delta 33 \mathrm{~S}$ (left) and $\delta^{56} \mathrm{Fe} \delta 56 \mathrm{Fe}$ (right) values for both nodules (nodule 1 in grey and nodule 2 in white). The pyrite nodules show two main $\Delta^{33} S \Delta 33 S$ peaks, one with positive $\Delta^{33} S \Delta 33 S$ value and another one with negative $\Delta^{33} S \Delta 33 S$ value and two main $\delta^{56} \mathrm{Fe} \delta 56 \mathrm{Fe}$ peaks, one with negative $\delta^{56} \mathrm{Fe} \delta 56 \mathrm{Fe}$ value and another one with $\delta^{56} \mathrm{Fe} \delta 56 \mathrm{Fe}$ value close to $0 \%$. The similar isotopic compositions suggest a shared origin of the two nodules.
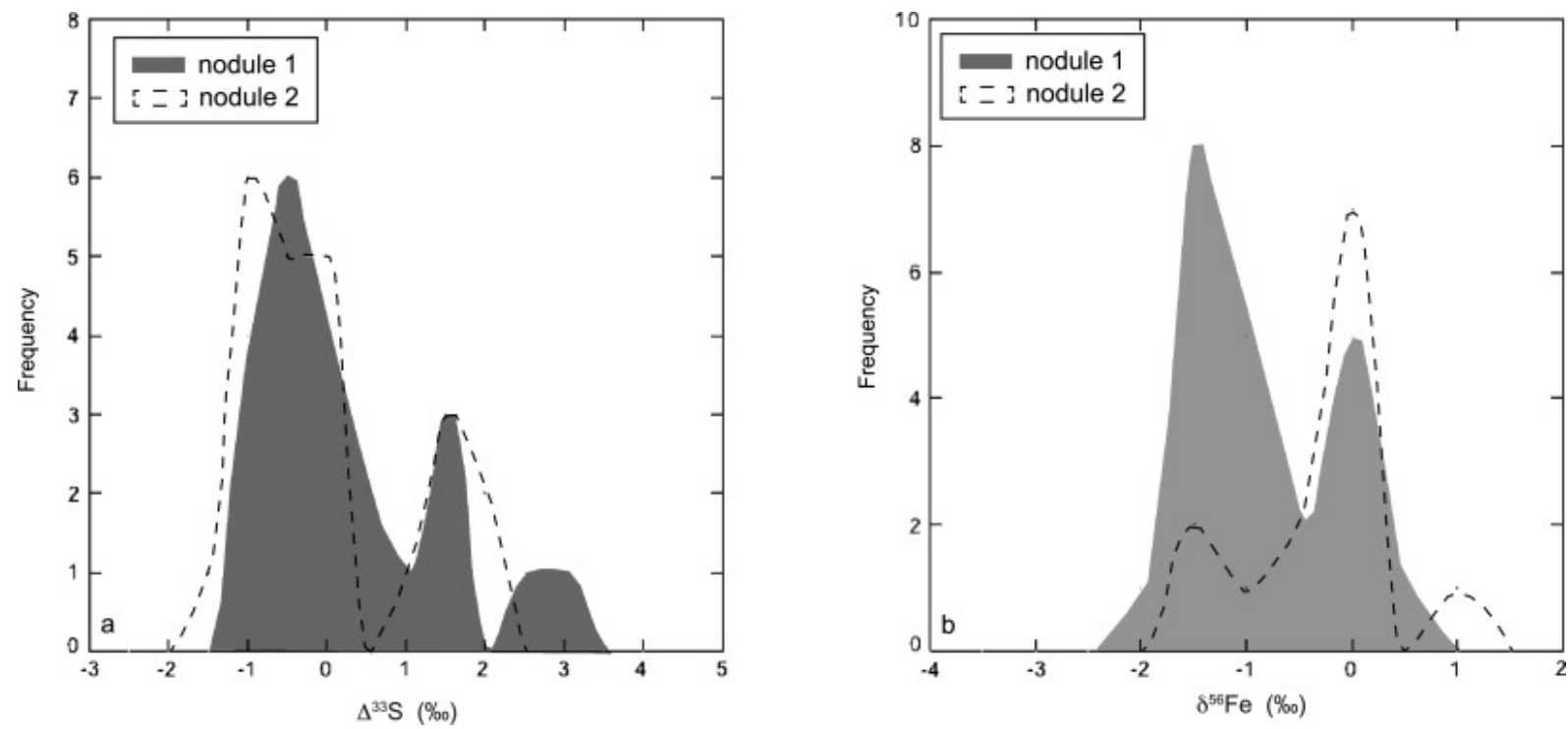

Figure 7: $\delta^{56} \mathrm{Fe} \delta 56 \mathrm{Fe}$ and $\Delta^{33} \mathrm{~S} \Delta 33 \mathrm{~S}$ values for nodule 1 (in white) and nodule 2 (in black). Previous data obtained for the Belingwe pyrite by Archer and Vance (2006) is plotted in grey, and the DIR and BSR processes are represented by the two curves reflecting different dissolved Fe concentrations.

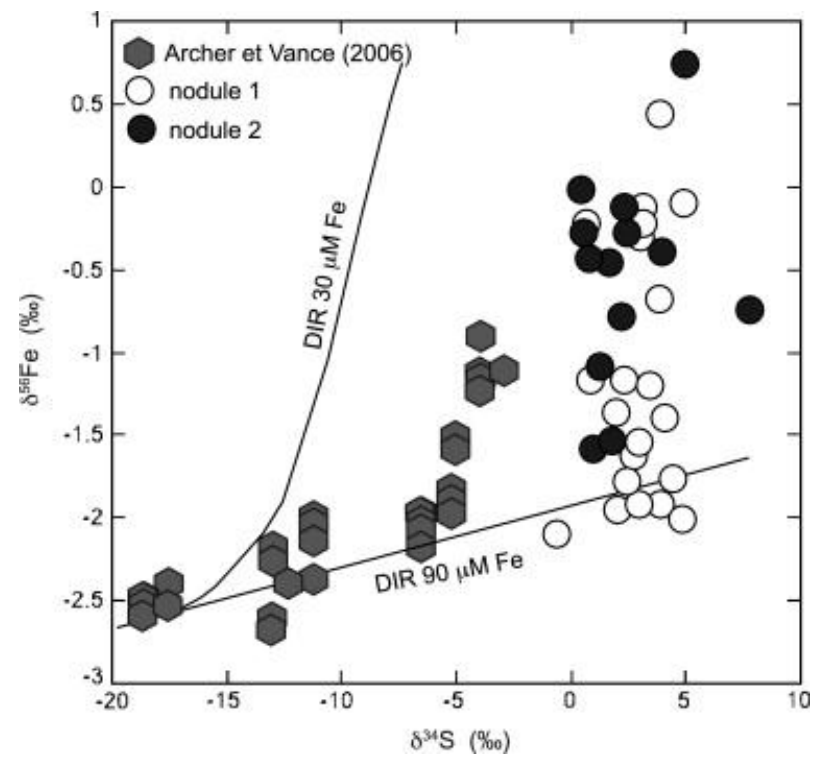

Figure 8: Probability density plot of $\delta^{56} \mathrm{Fe} \delta 56 \mathrm{Fe}$ values for nodule 1 and calculated values assuming Rayleigh distillation process (in red). The measured values are plotted separately for the rim (grey) and core (white). Note that the Rayleigh distillation process reproduces the entire range of $\delta^{56} \mathrm{Fe} \delta 56 \mathrm{Fe}$ values measured in the nodule. (For interpretation of the references to color in this figure legend, the reader is referred to the web version of this article.) 


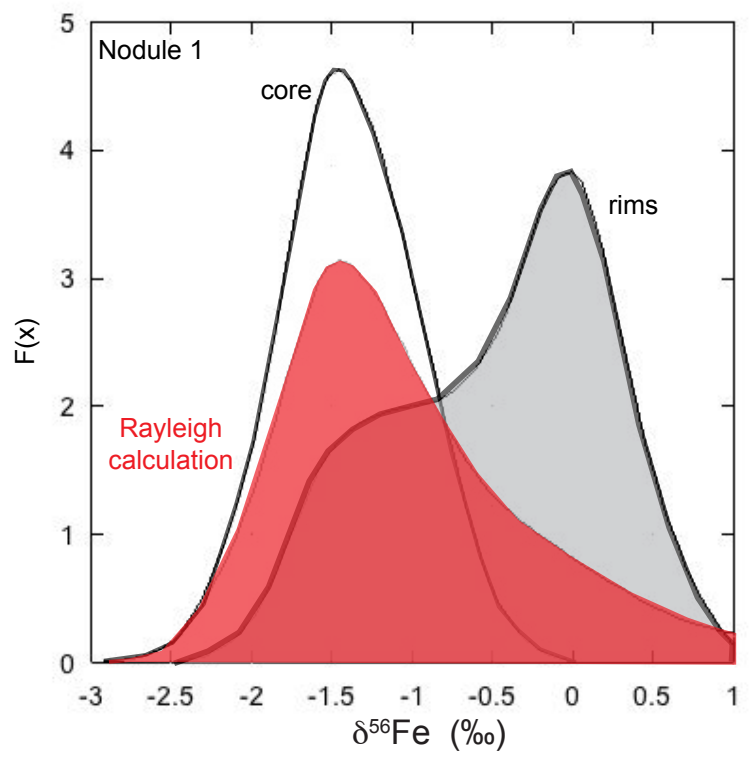

Figure 9: Model of nodule growth by migration and dissolution and precipitation of pyrite precursors in the organic matter-rich sediment during diagenesis. The core of the nodule (a) was precipitated by dissolution of mackinawite in the presence of $\mathrm{H}_{2} \mathrm{~S}$, produced by breaking $\mathrm{S}_{8}$ rings and biological reduction. By the end of the core growth (b), small, disseminated greigite grains were formed from the remaining dissolved mackinawite $\left(\mathrm{FeS}_{\mathrm{m}}\right)$ clusters and gradually accumulating polysulfide from broken $\mathrm{S}_{8}$ rings in sediment pore waters (b). Finally, the coarsegrained rim of the nodules and the disseminated pyrites were formed by the dissolution of the small, disseminated greigite grains during deep burial at higher temperature and in the presence of late diagenetic fluids with different trace element composition from that of the early diagenetic fluids (c). 

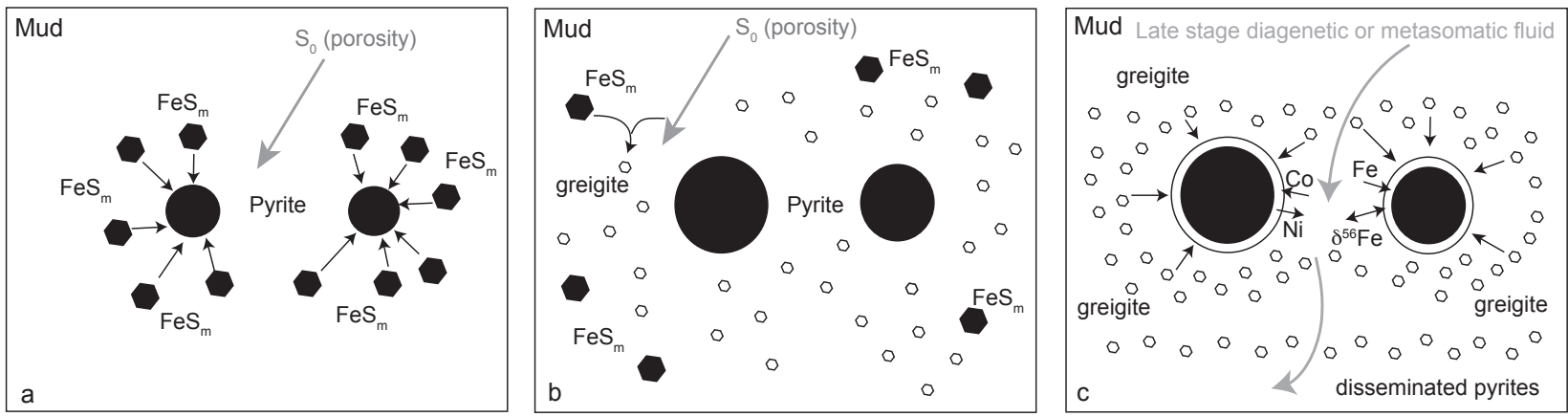

Supplementary materials:

Table S1: Trace element concentrations measured across nodule 2 by both LA-ICP-MS and EPMA (four profiles). Profile 1 of EPMA is adjacent to the profile measured by LA-ICP-MS.

Supplementary materials: 1 - Geological Map of the Bubi Greenstone Belt, 2 - Stratigraphic log of the drill core, 3 - SIMS analyses with spot locations shown, 4 - Trace element concentration profiles.

\section{References}

Agangi, A., Hofmann, A., Wohlgemuth-Ueberwasser, C.C., 2013. Pyrite Zoning as a Record of Mineralization in the Ventersdorp Contact Reef, Witwatersrand Basin, South Africa. Economic Geology 108, 1243-1272.

Archer, C., Vance, D., 2006. Coupled Fe and S isotope evidence for Archean microbial $\mathrm{Fe}(\mathrm{III})$ and sulfate reduction. Geology 34, 153-156. 
Bao, H., Rumble III, D., Lowe, D.R., 2007. The five stable isotope compositions of Fig Tree barites: Implications on sulfur cycle in ca. 3.2 Ga oceans. Geochimica et Cosmochimica Acta 71, 4868-4879.

Beard, B.L., Johnson, C.M., Cox, L., Sun, H., Nealson, K.H., Aguilar, C., 1999. Iron Isotope Biosignatures. Science 285, 1889-1892.

Bekker, A., Holland, H.D., Wang, P.L., Rumble, D., Stein, H.J., Hannah, J.L., Coetzee, L.L., Beukes, N.J., 2004. Dating the rise of atmospheric oxygen. Nature 427, 117-120.

Berner, R.A., 1980. Early Diagenesis Princeton University Press, Princeton

Berner, R.A., 1984. Sedimentary pyrite formation: An update. Geochimica et Cosmochimica Acta 48, 605-615.

Butler, I.B., Archer, C., Vance, D., Oldroyd, A., Rickard, D., 2005. Fe isotope fractionation on FeS formation in ambient aqueous solution. Earth and Planetary Science Letters 236, 430-442.

Canfield, D.E., 2001. Isotope fractionation by natural populations of sulfate-reducing bacteria. Geochimica et Cosmochimica Acta 65, 1117-1124.

Coleman, M.L., Raiswell, R., 1981. Carbon, oxygen and sulphur isotope variations in concretions from the Upper Lias of N.E. England. Geochimica et Cosmochimica Acta 45, 329340.

Dauphas, N., Rouxel, O., 2006. Mass spectrometry and natural variations of iron isotopes. Mass Spectrometry Reviews 25, 515-550.

Dziggel, A., Klemd, R., Stevens, G., 1998. Gold mineralization at Turk Mine, Zimbabwe: A geochemical and statistical investigation of the hydrothermally overprinted host rock. .

Fabre, S., Nedelec, A., Poitrasson, F., Strauss, H., Thomazo, C., Nogueira, A., 2011. Iron and sulphur isotopes from the Carajas mining province (Para, Brazil): Implications for the oxidation of the ocean and the atmosphere across the Archaean,Proterozoic transition. Chemical Geology 289, 124-139.

Farquhar, J., Bao, H., Thiemens, M., 2000. Atmospheric Influence of Earth's Earliest Sulfur Cycle. Science 289, 756-758. 
Farquhar, J., Cliff, J., Zerkle, A.L., Kamyshny, A., Poulton, S.W., Claire, M., Adams, D., Harms, B., 2013. Pathways for Neoarchean pyrite formation constrained by mass-independent sulfur isotopes. Proceedings of the National Academy of Sciences.

Farquhar, J., Savarino, J., Airieau, S., Thiemens, M.H., 2001. Observation of wavelength-sensitive mass-independent sulfur isotope effects during SO2 photolysis: Implications for the early atmosphere. J. Geophys. Res. 106, 32829-32839.

Farquhar, J., Wing, B., 2003. Multiple Sulfur isotopes and the evolution of the atmosphere. Earth and Planetary Science Letters 213, 1-13.

Farquhar, J., Wu, N., Canfield, D.E., Oduro, H., 2010. Connections between Sulfur Cycle Evolution, Sulfur Isotopes, Sediments, and Base Metal Sulfide Deposits. Economic Geology 105, 509-533.

Gilbert, S., Danyushevsky, L., Robinson, P., Wohlgemuth-Ueberwasser, C., Pearson, N., Savard, D., Norman, M., Hanley, J., 2013. A Comparative Study of Five Reference Materials and the Lombard Meteorite for the Determination of the Platinum-Group Elements and Gold by LA-ICP-MS. Geostandards and Geoanalytical Research 37, 51-64.

Guilbaud, R., Butler, I.B., Ellam, R.M., 2011. Abiotic Pyrite Formation Produces a Large Fe Isotope Fractionation. Science 332, 1548-1551.

Heimann, A., Johnson, C.M., Beard, B.L., Valley, J.W., Roden, E.E., Spicuzza, M.J., Beukes, N.J., 2010. Fe, C, and O isotope compositions of banded iron formation carbonates demonstrate a major role for dissimilatory iron reduction in $\sim 2.5 \mathrm{Ga}$ marine environments. Earth and Planetary Science Letters 294, 8-18.

Hofmann, A., Bekker, A., Dirks, P., Gueguen, B., Rumble, D., Rouxel, O., 2013. Comparing orthomagmatic and hydrothermal mineralization models for komatiite-hosted nickel deposits in Zimbabwe using multiple-sulfur, iron, and nickel isotope data. Mineralium Deposita, $1-26$.

Hofmann, A., Bekker, A., Rouxel, O., Rumble, D., Master, S., 2009. Multiple sulphur and iron isotope composition of detrital pyrite in Archaean sedimentary rocks: A new tool for provenance analysis. Earth and Planetary Science Letters 286, 436-445.

Hofmann, A., Kusky, T., 2004. The Belingwe Greenstone Belt: Ensialic or Oceanic?, in: Timothy, M.K. (Ed.), Developments in Precambrian Geology. Elsevier, pp. 487-538. 
Homoky, W.B., Severmann, S., Mills, R.A., Statham, P.J., Fones, G.R., 2009. Pore-fluid Fe isotopes reflect the extent of benthic Fe redox recycling: Evidence from continental shelf and deep-sea sediments. Geology 37, 751-754.

Hu, G.X., Rumble III, D., Wang, P.L., 2003. An ultraviolet laser microprobe for the in situ analysis of multisulfur isotopes and its use in measuring Archean sulfur isotope massindependent anomalies. Geochimica et Cosmochimica Acta 67, 3101-3118.

Johnson, C., Beard, B., Beukes, N., Klein, C., O'Leary, J., 2003. Ancient geochemical cycling in the Earth as inferred from $\mathrm{Fe}$ isotope studies of banded iron formations from the Transvaal Craton. Contributions to Mineralogy and Petrology 144, 523-547.

Johnson, C.M., Beard, B.L., 2005. Biogeochemical Cycling of Iron Isotopes. Science 309, 1025-1027.

Johnson, C.M., Beard, B.L., Roden, E.E., 2008. The Iron Isotope Fingerprints of Redox and Biogeochemical Cycling in Modern and Ancient Earth. Annual Review of Earth and Planetary Sciences 36, 457-493.

Johnson, C.M., Beard, B.L., Roden, E.E., Newman, D.K., Nealson, K.H., 2004. Isotopic Constraints on Biogeochemical Cycling of Fe. Reviews in Mineralogy and Geochemistry 55, $359-408$.

Johnston, D.T., 2011. Multiple Sulfur Isotopes and the evolution of Earth's surface sulfur cycle Earth Science Reviews 106, 161-183.

Kakegawa, T., Kawai, H., Ohmoto, H., 1998. Origins of pyrites in the 2.5 Ga Mt. McRae Shale, the Hamersley District, Western Australia. Geochimica et Cosmochimica Acta 62, 32053220 .

Kamber, B.S., Whitehouse, M.J., 2007. Micro-scale sulphur isotope evidence for sulphur cycling in the late Archean shallow ocean. Geobiology 5, 5-17.

Large, R.R., Danyushevsky, L., Hollit, C., Maslennikov, V., Meffre, S., Gilbert, S., Bull, S., Scott, R., Emsbo, P., Thomas, H., Singh, B., Foster, J., 2009. Gold and Trace Element Zonation in Pyrite Using a Laser Imaging Technique: Implications for the Timing of Gold in Orogenic and Carlin-Style Sediment-Hosted Deposits. Economic Geology 104, 635-668.

Marin-Carbonne, J., Rollion-Bard, C., Luais, B., 2011. In-situ measurements of iron isotopes by SIMS: MC-ICP-MS intercalibration and application to a magnetite crystal from the Gunflint chert. Chemical Geology 285, 50-61. 
Oduro, H., Harms, B., Sintim, H.O., Kaufman, A.J., Cody, G., Farquhar, J., 2011. Evidence of magnetic isotope effects during thermochemical sulfate reduction. Proceedings of the National Academy of Sciences 108, 17635-17638.

Ohmoto, H., Watanabe, Y., Ikemi, H., Poulson, S.R., Taylor, B.E., 2006. Sulphur isotope evidence for an oxic Archaen atmosphere. Nature 442, 908-911.

Ono, S., Beukes, N.J., Rumble, D., 2009. Origin of two distinct multiple-sulfur isotope compositions of pyrite in the 2.5 Ga Klein Naute Formation, Griqualand West Basin, South Africa. Precambrian Research 169, 48-57.

Ono, S., Eigenbrode, J.L., Pavlov, A.A., Karecha, P., Rumble III, D., Kasting, J.F., Freeman, K.H., 2003a. New insights into Archean sulfur cycle from mass-independent sulfur isotope records from the Hamersley Basin, Australia. Earth and Planetary Science Letters 213, 15-30.

Ono, S., Eigenbrode, J.L., Pavlov, A.A., Kharecha, P., Rumble Iii, D., Kasting, J.F., Freeman, K.H., 2003b. New insights into Archean sulfur cycle from mass-independent sulfur isotope records from the Hamersley Basin, Australia. Earth and Planetary Science Letters 213, 15-30.

Pavlov, A.A., Kasting, J.F., 2002. Mass-Independant Fractionation of Sulfur Isotopes in Archean sediments: Strong evidence for an anoxic Archean Atmosphere. Astrobiology 2, 27-41.

Percak-Dennett, E.M., Beard, B.L., Xu, H., Konishi, H., Johnson, C.M., Roden, E.E., 2011. Iron isotope fractionation during microbial dissimilatory iron oxide reduction in simulated Archaean seawater. Geobiology 9, 205-220.

Philippot, P., Van Zuilen, M., Rollion-Bard, C., 2012. Variations in atmospheric sulphur chemistry on early Earth linked to volcanic activity. Nature Geosciences 5, 668-674.

Planavsky, N., Rouxel, O., Bekker, A., Shapiro, R., Fralick, P., Knudsen, A., 2009. Ironoxidizing microbial ecosystems thrived in late Paleoproterozoic redox-stratified oceans. Earth and Planetary Science Letters 286, 230-242.

Planavsky, N., Rouxel, O.J., Bekker, A., Hofmann, A., Little, C.T.S., Lyons, T.W., 2012. Iron isotope composition of some Archean and Proterozoic iron formations. Geochimica et Cosmochimica Acta 80, 158-169. 
Polyakov, V.B., Clayton, R.N., Horita, J., Mineev, S.D., 2007. Equilibrium iron isotope fractionation factors of minerals: Reevaluation from the data of nuclear inelastic resonant X-ray scattering and Mossbauer spectroscopy. Geochimica et Cosmochimica Acta 71, 3833-3846.

Polyakov, V.B., Soultanov, D.M., 2011. New data on equilibrium iron isotope fractionation among sulfides: Constraints on mechanisms of sulfide formation in hydrothermal and igneous systems. Geochimica et Cosmochimica Acta 75, 1957-1974.

Prendergast, M.D., 2003. The Nickeliferous Late Archean Reliance Komatiitic Event in the Zimbabwe Craton--Magmatic Architecture, Physical Volcanology, and Ore Genesis. Economic Geology 98, 865-891.

Raiswell, R., Berner, R.A., 1986. Pyrite and organic matter in Phanerozoic normal marine shales. Geochimica et Cosmochimica Acta 50, 1967-1976.

Rickard, D., 2013. Sulfidic Sediments and sedimentary rocks

Rickard, D., Luther, G.W., 2007. Chemistry of Iron Sulfides. Chemical Reviews 107, 514-562.

Rouxel, O., Dobbek, N., Ludden, J., Fouquet, Y., 2003. Iron isotope fractionation during oceanic crust alteration. Chemical Geology 202, 155-182.

Rouxel, O., Shanks Iii, W.C., Bach, W., Edwards, K.J., 2008. Integrated Fe- and Sisotope study of seafloor hydrothermal vents at East Pacific Rise 9-10 $\mathrm{N}$. Chemical Geology 252, 214-227.

Rouxel, O.J., Bekker, A., Edwards, K.J., 2005. Iron Isotope Constraints on the Archean and Paleoproterozoic Ocean Redox State. Science 307, 1088-1091.

Saggerson, E.P., Turner, L.M., 1976. A review of the distribution of metamorphism in the ancient Rhodesian craton. Precambrian Research 3, 1-53.

Severmann, S., Johnson, C.M., Beard, B.L., McManus, J., 2006. The effect of early diagenesis on the $\mathrm{Fe}$ isotope compositions of porewaters and authigenic minerals in continental margin sediments. Geochimica et Cosmochimica Acta 70, 2006-2022.

Severmann, S., Lyons, T.W., Anbar, A., McManus, J., Gordon, G., 2008. Modern iron isotope perspective on the benthic iron shuttle and the redox evolution of ancient oceans. Geology 36, 487-490. 
Shen, Y., Farquhar, J., Masterson, A., Kaufman, A.J., Buick, R., 2009. Evaluating the role of microbial sulfate reduction in the early Archean using quadruple isotope systematics. Earth and Planetary Science Letters 279, 383-391.

Sim, M.S., Bosak, T., Ono, S., 2011. Large Sulfur Isotope Fractionation Does Not Require Disproportionation. Science 333, 74-77.

Steadman, J.A., Large, R.R., Meffre, S., Bull, S.W., 2013. Age, origin and significance of nodular sulfides in 2680\&\#xa0;Ma carbonaceous black shale of the Eastern Goldfields Superterrane, Yilgarn Craton, Western Australia. Precambrian Research 230, 227-247.

Stone, A.G., Cumming, B., Foy, R.A., 1994. Final Report on work done from 01/04/91 to 31/03/94, EP0690-Gwampa Valley bulletin Z329 FalconBridge Exploration Zimbabwe.

Strauss, H., 2003. Sulphur isotopes and the early Archaean sulphur cycle. Precambrian Research 126, 349-361.

Thiemens, M.H., 2001. The Mass-Independent Ozone Isotope Effect. Science 293, 226.

Thomassot, E., Cartigny, P., Harris, J.W., Lorand, J.P., Rollion-Bard, C., Chaussidon, M., 2009. Metasomatic diamond growth: A multi-isotope study (13C, 15N, 33S, 34S) of sulphide inclusions and their host diamonds from Jwaneng (Botswana). Earth and Planetary Science Letters 282, 79-90.

Tsikos, H., Matthews, A., Erel, Y., Moore, J.M., 2010. Iron isotopes constrain biogeochemical redox cycling of iron and manganese in a Palaeoproterozoic stratified basin. Earth and Planetary Science Letters 298, 125-134.

Ueno, Y., Ono, S., Rumble, D., Maruyama, S., 2008. Quadruple sulfur isotope analysis of ca. 3.5Ga Dresser Formation: New evidence for microbial sulfate reduction in the early Archean. Geochimica et Cosmochimica Acta 72, 5675-5691.

Whitehouse, M.J., Fedo, C.M., 2007. Microscale heterogeneity of Fe isotopes in >3.71 Ga banded iron formation from the Isua Greenstone Belt, southwest Greenland. Geology 35, 719-722.

Wilson, S.A., Ridley, W.I., Koenig, A.E., 2002. Development of sulfide calibration standards for the laser ablation inductively-coupled plasma mass spectrometry technique. Journal of Analytical Atomic Spectrometry 17, 406-409. 
Wohlgemuth-Ueberwasser, C.C., Ballhaus, C., Berndt, J., Paliulionyte, V.S.N., Meisel, T., 2007. Synthesis of PGE sulfide standards for laser ablation inductively coupled plasma mass spectrometry (LA-ICP-MS). Contributions to Mineralogy and Petrology 154, 607-617.

Yoshiya, K., Nishizawa, M., Sawaki, Y., Ueno, Y., Komiya, T., Yamada, K., Yoshida, N., Hirata, T., Wada, H., Maruyama, S., 2012. In situ iron isotope analyses of pyrite and organic carbon isotope ratios in the Fortescue Group: Metabolic variations of a Late Archean ecosystem. Precambrian Research 212-213, 169-193. 